Research paper

\title{
Role of big data and social media analytics for business to business sustainability: A participatory web context
}

\author{
Uthayasankar Sivarajah $^{\mathrm{a}, *}$, Zahir Irani ${ }^{\mathrm{a}}$, Suraksha Gupta ${ }^{\mathrm{b}}$, Kamran Mahroof ${ }^{\mathrm{a}}$ \\ ${ }^{a}$ University of Bradford, Emm Lane, Bradford BD9 4JL, United Kingdom \\ ${ }^{\mathrm{b}}$ Newcastle University, 102 Middlesex St, London E1 7EZ, United Kingdom
}

\section{A R T I C L E I N F O}

\section{Keywords:}

Participatory web

Marketing and operations

Big data

Social media analytics

Business sustainability

Business-to-business (B2B)

\begin{abstract}
A B S T R A C T
The digital transformation is an accumulation of various digital advancements, such as the transformation of the web phenomenon. The participatory web that allows for active user engagement and gather intelligence has been widely recognised as a value add tool by organisations of all shapes and sizes to improve business productivity and efficiency. However, its ability to facilitate sustainable business-to-business (B2B) activities has lacked focus in the business and management literature to date. This qualitative research is exploratory in nature and fills this gap through findings arising from interviews of managers and by developing taxonomies that highlight the capability of participatory web over passive web to enable different firms to engage in business operations. For this purpose, two important interrelated functions of business i.e. operations and marketing have been mapped against three dimensions of sustainability. Consequently, this research demonstrates the ability of big data and social media analytics within a participatory web environment to enable B2B organisations to become profitable and remain sustainable through strategic operations and marketing related business activities. The research findings will be useful for both academics and managers who are interested in understanding and further developing the business use of participatory web tools to achieve business sustainability. Hence, this may be considered as a distinct way of attaining sustainability.
\end{abstract}

\section{Introduction}

The term 'Digital transformation' has broad nuances and is attributed to driving various forms of technological innovation in both industrial and societal domains (Gray \& Rumpe, 2017). Digital transformation generally refers to the globally accelerated process of technical adaptation by individuals, organisations, communities and nations resulting from digitalisation (Westerman, Bonnet, \& McAfee, 2014). The focus of this study is the digital transformation of the web phenomenon, which has experienced a paradigm shift from a passive information source towards the collaborative and intelligent participatory web, which encourages active user engagement and contribution. The participatory web provides quick access to information and intelligence while also influencing the speed and frequency at which information travels thus presenting significant opportunities for managers to communicate and engage with stakeholders almost instantaneously. The enormous amounts of data generated and gathered from social networking sites (SNS) combined with the limited academic insights into big data and social media analytics, particularly from a business to business (B2B) context makes participatory web a highly relevant point of discussion.

The digitisation of almost every aspect of business and organisational activties has subsequently led to the onset of large datasets for analysing purposes, which through big data and analytical tools can create actionable insights for delivering sustainable value, improving business performance and providing competitive advantage (Wamba et al., 2017). Therefore, sustainability in current times can be considered as a corporate-performance metrics for organisations (Bughin, Chui, \& Manyika, 2010), becoming increasingly critical for organisations, given the ability of divergent set of stakeholders to actively monitor the extent to which organisations pursuit and engage with sustainability initiatives. As such, the significant rise in the sustainability efforts of organisations in the recent decades is unsurprising, mainly attributed to the increased demand and expectations placed on organisations by society (Johnson, Redlbacher, \& Schaltegger, 2018). Moreover, it is argued that effective stakeholder engagement is the 'most influential source of competitive advantage' for corporate sustainability (Rodriguez-Melo and Mansouri, 2011, p. 548). This focus

\footnotetext{
* Corresponding author.

E-mail addresses: u.sivarajah@bradford.ac.uk (U. Sivarajah), z.irani@bradford.ac.uk (Z. Irani), Suraksha.Gupta@newcastle.ac.uk (S. Gupta), k.a.mahroof@bradford.ac.uk (K. Mahroof).
} 
has led to a shift in how organisations engage with their stakeholders for corporate sustainability, with much emphasis placed on stakeholder engagement, which can be positively enhanced by B2B (Youssef, Johnston, AbdelHamid, Dakrory, \& Seddick, 2018), particularly given that the way in which an organisation's sustainable practices and operations are managed and articulated has become an integral part of B2B marketing and communications strategy (Kapitan, Kennedy, \& Berth, 2019).

Yet, despite the potential of participatory web tools, research into participatory web focuses largely on the consumer in a business-toconsumer (B2C) domain (Michaelidou, Siamagka, \& Christodoulides, 2011), emphasised through the fact that the social media and B2C has attracted much academic attention (Kaplan \& Haenlein, 2010; Kietzmann, Hermkens, McCarthy, \& Silvestre, 2011; Trusov, Bucklin, \& Pauwels, 2009). As there is a lack of understanding about the role that participatory web plays in a B2B environment, these studies have encouraged the authors to explore whether key features of participatory web coupled with Big Data and Social Media analytics can enable businesses that engage with other firms to identify opportunities of supporting sustainability through their business activities. While there is no universally accepted definition of B2B sustainability, Kapitan et al. (2019, p. 96) refer to it as an approach to influence clients' perceptions of B2B brand sustainability, 'with the aim of achieving a trusted position sustainable superiority that yields further investment in sustainable products and production processes'. Furthermore, Sheth and Sinha (2015), loosely refer to B2B sustainability as the marketing act of B2B brands who closely link economic, social and environmental initiatives as part of sustainability marketing and thereby brand building.

Against this backdrop, the ability of participatory web to allow interactions and provide intelligence between managers of a firm with other stakeholders for participating in their business functions in the role of a service provider needs to be understood. Our study therefore dwells on the findings of various studies that explain how participatory web helps in the development of a mutual understanding between participants as individuals, creates knowledge and intelligence of their diverse needs and improves efficiency of delivery capabilities of their businesses (Pan \& Scarbrough, 1998; Tomkovicz, 2002). More generally, it is reported that organisations are utilising big data analytics for a number of reasons, such as improving transparency, decisionmaking, as well as to improve collaboration (Waller and Fawcett, 2013, Schoenherr and Cheri, 2015, Hazen et al., 2014, Wang et al., 2016, Kache and Seuring, 2017). There is no denying the increasing role of big data analytics from several domains, Bughin et al. (2010) highlight studies in big data and sustainability for firms in the auto industry. However, given the rise in studies which aim to provide information on the application of big data analytics to improve environmental sustainability (Song et al., 2017; Song, Fisher, Wang, \& Cui, 2016; Zhang, Ren, Liu, \& Si, 2017) and social sustainability (Liu \& Zhang, 2017; Song et al., 2017), it is surprising that majority of these studies lack practical insights (Sivarajah et al., 2017) and merely offer conceptual and anecdotal evidences (Bughin et al., 2010; Dubey et al., 2017; Jeble et al., 2018). Additionally, while studies acknowledge big data analytics and its contributions to sustainability, there remains a lack of practical insights into the types of techniques which can be employed by organisations to leverage sustainability from their use of analytics. Accordingly, this research enquiry raises the questions listed below:

- How can participatory web enable organiations to orient business to business practices towards sustainability?

- What big data and social media analytics techniques can be used by organisations to support their business to business sustainability initiatives?

- What is the impact of intelligence gathered through big data and social media analytics for driving business to business sustainability initiatives?
This research answers the questions raised by reviewing current understanding about the benefits of participatory web for businesses in a B2B context and its ability to convert business practices into sustainability initiatives. Participatory web provides a dynamic virtual space for interaction and intelligence that encourages stakeholders to participate in a very open manner (Forgues \& Koskela, 2009). A synthesis of literature on technology specifically social media analytics, sustainability, operations and marketing provides the theoretical basis for this discussion in the form of taxonomies and contribute to academic knowledge about the use of participatory web technologies as a tool for achievement of business sustainability. The taxonomies developed are grounded in the normative literature and then empirically validated through semi-structured interviews with practitioners (Dao, Langella, \& Carbo, 2011; Elkington, 2004; Keller \& Hüsig, 2009). In doing so, it has led to the proffering of: (a) models associated with business sustainability; (b) ICT enablers for business sustainability; (c) models of business sustainability that leverage new technologies and Participatory web and, (d) the capabilities of big data and social media analytics for business sustainability. These taxonomies identify current boundaries of research in existence about the topic and provide a richer picture and direct researchers towards emerging areas of related interest by linking technology and marketing with operations for sustainability. It must also be noted that while the promise of big data is widely reported, with it being attributed to providing highly useful information, Sivarajah et al. (2017) and Michael and Miller (2013) also refer to the new challenges it brings, in terms of how much data to store, the costs associated with storage, whether the data will be secure, and how long it must be maintained.

\section{Sustainability in the business context}

Sustainability, according to the World Commission Report on Environment and Development (1987, p. 41), is a strategy that helps a business "to meet its current requirements without compromising its ability to meet future needs". Although researchers tend to interpret sustainability with reference to environmental issues (Wu, Huang, Kuo, $\& \mathrm{Wu}, 2010$ ), there is an emerging consensus about the three dimensions of sustainability, also referred to as the 'triple bottom line' in the academic literature (Crittenden, Crittenden, Ferrell, Ferrell, \& Pinney, 2011; Elkington, 1998; Melville, 2010). The theory of triple bottom line proposed by Elkington (1998) draws upon three key facets of sustainability for managers to consider, namely, economic, social and environmental. While the economic aspect refers to the profit-making ability of a business (Hill, 2001), the social dimension refers to an organisation's ability to give back to the community (Dyllick \& Hockerts, 2002) and the environmental aspect relates to the initiatives that a business undertakes to conserve natural resources while making delivery (Melville, 2010). A business is considered to be truly sustainable if it simultaneously adheres to all these three facets (Elkington, 1998; Hauger \& Kock, 2007).

Firms can achieve sustainability by catering to the individual needs of different stakeholder constituencies (Heath \& Norman, 2004). The specific needs of different stakeholders make sustainability a complex phenomenon for managers, as they struggle to identify and deploy strategies that accomplish sustainability (Chabowski, Mena, \& GozalezPandron, 2011; Connelly, Ketchen, \& Slater, 2011). The literature discusses the role of marketing in the identification of needs, operations in the fulfillment of those needs and technology to improve efficiency of marketing and operations (Melville, Kraemer, \& Gurbaxani, 2004; Merono-Cerdan \& Soto-Acosta, 2007). Dyllick and Hockerts (2002) highlight the need for companies in a B2B setting to identify strategies that can help them achieve sustainability by addressing issues such as eco-efficiency and socio-efficiency. Eco-efficiency is the term used by Dyllick and Hockerts (2002) with reference to the marketing-based concept that requires environmentally friendly and competitively priced products to satisfy stakeholder needs and improve their quality 
of life. Socio-efficiency deals with operations to minimise the adverse impact of unforeseen events such as staff accidents at work (Dyllick \& Hockerts, 2002). Different aspects of a business when synchronised to develop ecological and socio-efficiency can lead to superior business performance (Hart \& Milstein, 2003). The concept of sustainability engages stakeholders by (a) raising awareness of sustainability related issues (b) articulation of sustainability-oriented requirements and (c) verifying indicators of sustainability related progress by matching them with business practices (Hill, 2001). Stakeholder engagement is referred as a process that 'creates a dynamic context of interaction, mutual respect, dialogue and change, not a unilateral management of stakeholders' (Andriof, Waddock, Husted, \& Rahman, 2002, p. 9) and a vital milestone in an organisations corporate social responsibility (CSR) policy, as it fosters a two-way dialogue between the organisation and the stakeholder in which both parties can mutually learn from such connections, allowing for expectations and preconceptions to be effectively aligned. (Manetti, 2011; Owen, Swift, \& Hunt, 2001).

The existing models of sustainability as described highlight some of the key practices that large companies can adopt by integrating their general management systems such as total quality management with environment management systems in a B2B context (Allenby, 2011). However, there is a lack of understanding about the tools that can help managers to integrate business practices with sustainability. Table 1 presents a taxonomy that extrapolates different models of sustainability from the literature to draw out parallels and differences. It also reflects on the capability of web-based tools to manage information and communication in a way that orients managerial actions and business initiatives towards sustainability.

\section{Web-based technologies and business sustainability}

Social media has become a pertinent platform for public engagement, inter-organisational relationships, and public information in recent years (Rybako \& Seltzer, 2010), allowing organisations to integrate SNS into their business strategies in order to derive value from areas such as customer traffic, customer loyalty and retention, brand awareness and reputation (Montalvo, 2016). However, while B2B analytics is valued at more than three and half times that of B2C analytics (Kalapesi et al., 2010), the interest and subsequent adoption of social media and big data analytics by B2B organisations has been unhurried when compared to that of B2C. Organisations are required to manage sustainability initiatives in a more systematic and data-driven manner with the help of technology (Prattipati, 2010). Research conducted by McKinsey on the impact of participatory web technologies indicate that positioning of technologies to create networked organisations that promote innovative collaboration among stakeholders such as employees, customers, and partners is associated with market share gains (Bughin et al., 2010). Thus, with technological advancements allowing organisations to monitor, measure and customize at a greater attention to detail than previously seen, and the notion of collaboration at scale may further facilitate the sustainability efforts of organisations, through a greater exchange of information between organisations. The various models of sustainability explored were reviewed to understand the application of technology from different perspectives of business management activities. The review highlights that web-based technologies have changed the way managers conduct business (Dunn \& Varano, 1999; Kim, Yue, Hall, \& Gates, 2009). Primary improvement in

Table 1

A taxonomy of business sustainability.

\begin{tabular}{|c|c|c|c|c|}
\hline Sustainability models & Constructs of sustainability & Description of models & Application domain & Reference(s) \\
\hline Triple Bottom Line & $\begin{array}{l}\text { - Economic } \\
\text { - Social } \\
\text { - Environmental }\end{array}$ & $\begin{array}{l}\text { The fundamental concept of integrating all three } \\
\text { dimensions of sustainability (economic, social and } \\
\text { environmental) into the business context }\end{array}$ & $\begin{array}{l}\text { Business } \\
\text { Sustainability }\end{array}$ & Elkington (2004) \\
\hline $\begin{array}{l}\text { Extended Corporate } \\
\text { Sustainability Framework }\end{array}$ & $\begin{array}{l}\text { - Business Case } \\
\text { o Eco-efficiency } \\
\text { o Socio-efficiency } \\
\text { - Natural Case } \\
\text { o Eco-effectiveness } \\
\text { o Sufficiency } \\
\text { - Societal Case } \\
\text { o Socio-effectiveness } \\
\text { o Ecological equity }\end{array}$ & $\begin{array}{l}\text { A comprehensive model in line with the three main } \\
\text { dimensions (economic, environmental and social) } \\
\text { but further exploring paradigms that a business } \\
\text { should fulfil to be sustainable }\end{array}$ & $\begin{array}{l}\text { Business Strategy } \\
\text { and Environment }\end{array}$ & $\begin{array}{l}\text { Dyllick and } \\
\text { Hockerts (2002) }\end{array}$ \\
\hline $\begin{array}{l}\text { Market-oriented Sustainability } \\
\text { Framework }\end{array}$ & $\begin{array}{l}\text { - DNA (a metaphor used by the author to } \\
\text { clarify the workings of an organisation } \\
\text { and how sustainability may be } \\
\text { implemented) } \\
\text { - Stakeholder involvement } \\
\text { - Performance Management }\end{array}$ & $\begin{array}{l}\text { Captures the fundamental triggers behind businesses } \\
\text { following socially responsible practices to achieve } \\
\text { sustainability }\end{array}$ & Marketing & $\begin{array}{l}\text { Crittenden et al. } \\
\text { (2011) }\end{array}$ \\
\hline $\begin{array}{l}\text { Multidimensional Sustainable- } \\
\text { Value Creation Model }\end{array}$ & $\begin{array}{l}\text { - Growing profits and reducing risk through } \\
\text { pollution prevention } \\
\text { - Enhancing reputation and legitimacy } \\
\text { through product stewardship } \\
\text { - Accelerating innovation and repositioning } \\
\text { through clean technology } \\
\text { - Crystallising the firm's growth path and } \\
\text { trajectory through a sustainability vision }\end{array}$ & $\begin{array}{l}\text { A framework that captures and illustrates the } \\
\text { challenges of sustainability and the creation of } \\
\text { shareholder value while simultaneously attaining } \\
\text { business sustainability }\end{array}$ & $\begin{array}{l}\text { Executive } \\
\text { Management }\end{array}$ & $\begin{array}{l}\text { Hart and Milstein } \\
(2003)\end{array}$ \\
\hline $\begin{array}{l}\text { Corporate Sustainability } \\
\text { Management Model } \\
\text { (CSMS) }\end{array}$ & $\begin{array}{l}\text { - Sustainable Development Policy } \\
\text { - Planning } \\
\text { - Implementation } \\
\text { - Communication } \\
\text { - Review and corrective action }\end{array}$ & $\begin{array}{l}\text { Model that encompasses the stages which will } \\
\text { enable businesses to manage sustainability in a } \\
\text { systematic and structured approach }\end{array}$ & $\begin{array}{l}\text { General } \\
\text { Management }\end{array}$ & Azapagic (2003) \\
\hline $\begin{array}{l}\text { TXU Practical model for } \\
\text { Sustainable Business } \\
\text { (DAFA Model) }\end{array}$ & $\begin{array}{l}\text { - Managing stakeholder dialogues to } \\
\text { identify issues } \\
\text { - Awareness-raising around sustainability } \\
\text { issues } \\
\text { - Facilitating the development of actions } \\
\text { and change } \\
\text { - Accounting through indicators and } \\
\text { reporting }\end{array}$ & $\begin{array}{l}\text { A practical behavioural framework adopted by a } \\
\text { company (TXU) which places great emphasis on the } \\
\text { concept of stakeholder engagement for business } \\
\text { sustainability }\end{array}$ & $\begin{array}{l}\text { Corporate } \\
\text { Environment }\end{array}$ & Hill (2001) \\
\hline
\end{tabular}




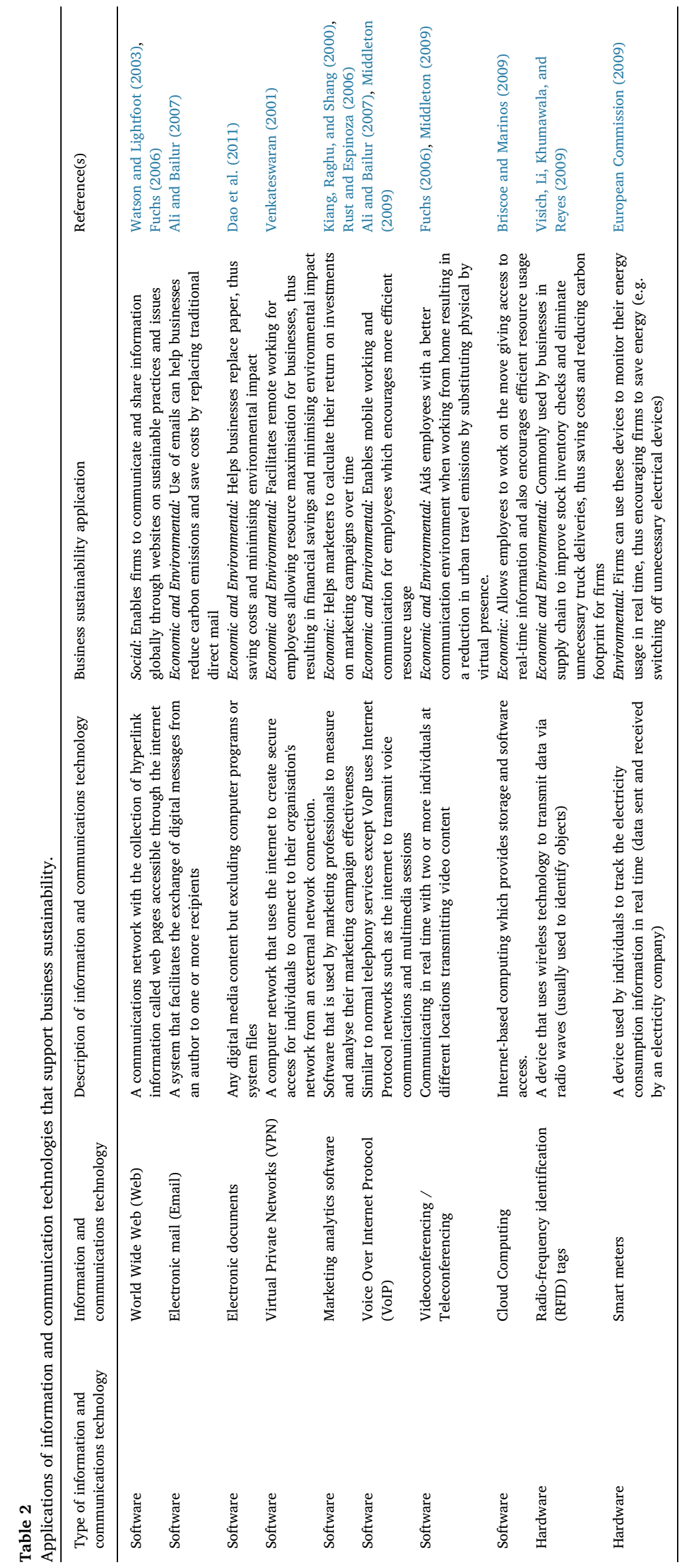


efficiency of businesses through the use of technology can be accounted for in the efficient use of information and its dispersion through technology as business communication (Hilty, 2008; Waage, Shah, \& Girshick, 2003). Innovative use of technology for communications has been acknowledged as a key feature that leads to improved efficiency and reduced cost of operations based on emerging technologies such as cloud computing, smart mobile devices and participatory web (Avgerou, 2008; European Commission Report, 2011; Teo, Chan, Wei, \& Zhang, 2003). Cloud computing technology allows for the development of energy-efficient data centres useful for creation, retrieval and dispersion of information efficiently (Khanagha, Volberda, Sindhu, \& Oshri, 2013; Muller, Sonehara, Echizen, \& Wohlgemuth, 2011). Furthermore, social media or smart mobile devices help build customer satisfaction by engaging them in an informal environment for application of empathy design (Dao et al., 2011). Table 2 presents a list of such technology applications as software and hardware technologies that support businesses in the achievement of sustainability practices.

While traditional passive web enabled firms to create a virtual representation of their firm in the form of corporate websites (Gill, Dickinson, \& Scharl, 2008), its contribution to the overall development of sustainability practices has been very limited (Kim et al., 2009). The ability of firms to communicate but not interact with stakeholders does not allow them to contradict or debate the information provided by companies (Cormode \& Krishnamurthy, 2008). The emergence of participatory web addressed such shortcomings by providing a range of features that were useful for building business capabilities (Kim et al., 2009). Participatory web acts as an umbrella term that encompasses web applications and websites differently from their predecessors in the early years of the Internet which is referred to as Passive web (Cormode \& Krishnamurthy, 2008). For the purpose of this research, the definition of Participatory web has been adopted from O'Reilly (2007) who refers to it as a simple and effective second generation of Web services that provide a social and participatory virtual platform for businesses to collaborate, network and interact with stakeholders.

Authors report that Participatory web technologies such as social media provides a dynamic platform for businesses to engage, interact and work together with stakeholders separate from creating a network of their constituencies (O'Reilly, 2007; Visser, 2010). Researchers recognised this dynamic space as a tool by which individual stakeholder constituencies can get heard by managers (Jones \& D'Agostino, 2009; Mrkwicka, Kiessling, \& Kolbe, 2009). Managers use interactions in virtual space for identifying the latent requirements of participants because it motivates free expression of thoughts and opinions (Cooke \& Buckley, 2007). According to Madden (2008) B2B stakeholders such as buyers, distributors, resellers and other parties are increasingly expecting B2C-like personalised experiences in the B2B setting. Participatory web applications provide a social platform useful not only for marketing purposes, but also for achieving objectives of operations and management functions by gathering useful user intelligence through a virtual environment (Kim et al., 2009).

\section{Integrative role of big data and social media analytics for business sustainability}

The growth in web usage has also led to organisations investing in a plethora of analytical tools to leverage value from this big data phenomenon. However, organisations are required to understand what big data analytics entails, as it is made up of various facets which include skills, technologies, applications and processes (Wang \& Hajli, 2017). Therefore, understanding how organisations can glean value from such technologies is paramount; particularly as success from such endeavours are not always guaranteed. Big data analytics provide decision support, traceability and predictive capabilities that can help transform organisational practices (Wang et al., 2017). However, having the ability and skills are paramount in doing so.

The explosion in the use of Social media in recent times has led to individuals seeking to gain information from the crowd as another avenue to traditional methods. Moreover, the availability of data resulting from social media consumption provides organisations with the ability to execute, timely, actionable, meaningful business decisions through the use of social media analytics. Stieglitz et al. $(2014 ; 89)$ define social media analytics as 'an emerging interdisciplinary research field that aims on combining, extending, and adapting methods for analysis of social media data'. The social media analytics process involves four distinct steps, data discovery, collection, preparation, and analysis (Stieglitz, Mirbabaie, Ross, \& Neuberger, 2018). This paper aims to explore the latter processes from a B2B perspective, i.e. how the collection and preparation (Big data) of social media data can be analysed (Social media analytics) for marketing and operations related activities to facilitate business sustainability.

Social media big data analytical techniques can be used to help organisations gain both holistic and personalised insights into the current situation in real time, thus allowing managers to take the most appropriate course of action, when required. Organisations need to be equipped with appropriate tools and skills to analyse and make sense of the data. The data derived from social media platforms provides organisations with detailed insights into consumer opinions and views relating to their brands and products, thus allowing the organisations to adapt and tailor decisions accordingly (Wu, Zhu, Wu, \& Ding, 2014). Previous studies have highlighted the majority of social media big data analysis relies techniques such as trend discovery, modelling, natural language processing (Ghani, Hamid, Targio Hashem, \& Ahmed, 2018), sentiment analysis (Ohbe, Ozono, \& Shintani, 2017), Social network analysis (Bonchi, Castillo, Gionis, \& Jaimes, 2011), and text mining (Reddick, Chatfield, \& Ojo, 2017). Furthermore, Shanthi and Pappa (2017) highlight that Natural language processing (NLP), Sentiment analysis, and Social network analysis are key big data analytics techniques used in social media, which all play a significant role in ultimately enhancing organisational decision-making. NLP works to understand the natural human language, in order to convert depictions of human language (such as textual documents) into more formal representations (numeric and symbolic data) that computer programs can manipulate at ease (Sharda et al., 2018). Sentiment analysis also applies NLP to understand what people feel about a certain topic, through sentiment detection, polarity classification, target identification and collection and aggregation processes which are underpinned by automated tools. This type of analysis is considered as the principal technique for many social media monitoring systems and trend analysis applications as it attempts to uncover how people feel about a particular topic by exploring opinions through automated tools. Through utilising natural language processing, text analytics and statistics, this technique automatically draws out user sentiments or opinions from text sources from words or phrases through to entire documents. It includes classifying consumer attitudes, sentiments, and opinions relating to the product, brand, or services of an organisation (Ohbe et al., 2017). Based on the words people use, sentiment analysis generally classifies with either positive, neutral or negative, across a range of polarity. The responsiveness during interactions in a Participatory web environment enables businesses to instantly obtain stakeholder responses to successfully satisfy their requirements (Watson \& Zinkhan, 1997). Bughin et al. (2010) refer to large organiations such as Ford Motor, PepsiCo, and Southwest Airlines as gaining personalised insights into their customer bases through mining data from social networks in real time. Through analysing consumer postings on social-media sites, these organisations are able to gauge the immediate impact of their marketing campaigns, whilst also gaining personalised insights into how their consumer sentiments regarding their brands may be altering.

Another key big data tool is social network analysis, which is used to gain an understanding of a group of people by mapping the relationships that link them as a network, this technique also helps identify key individuals and groups within their social network. Social network analysis uses a social network graph to map and measure relationships 
between people, groups, organisations, from social media using network theory of nodes and connections (Serrat, 2017). Through uncovering underlying structure, connections, and theoretical properties, social network analysis helps establish users and their associated social media relationships. Such relationships are detected as a result of user actions, such as two users connecting via social media as friends, although their relationships can also be established through peripheral behaviour such as tagging, commenting or sharing.

While B2B companies may be pressured by stakeholders, and even competitors to be more proactive on social media platforms, looking beyond these factors and that of general security risks, the social media trend of 'fake news' may also be considered as a determining factor for the adoption of social media analytics and engagement by B2B companies. Social media has widely been criticised for the spread of misinformation (Williamson, 2016). A recent study exploring social media misinformation from a healthcare context highlighted fake, misrepresentative and over-interpreted health news in social media as being a potential threat for public health, whereby top links in social media postings relating to common diseases in $40 \%$ cases contained distortion yet were shared 451,272 times in the period 2012-2017 (Waszak, Kasprzycka-Waszak, \& Kubanek, 2018). Castillo et al. (2013) highlights during the Chile earthquake, tweet ratio according to supporting tweet against misinterpreting tweets was at 1:1. Procter, Crump, Karstedt, Voss, and Cantijoch (2013) reveals a similar pattern, with the spread of false rumours on social media during the 2011 riots in the UK. Thus, with users not being able to distinguish too well between truth and hoaxes (Starbird et al., 2014), it is argued this can have severe consequences for organisations.

However, analysing social media can help organisations to identify and act on misleading social media postings (Waszak et al., 2018). Furthermore, Shu, Sliva, Wang, Tang, and Liu (2017) propose data mining techniques and social context features to expose and counteract misinformation from becoming viral. It is therefore argued that techniques such as sentiment analysis, social network analysis, text mining not only allow an organisation to identify key customer trends, sentiments and contexts, but such big data techniques allow organisation to proactively protect themselves from the increasingly growing trend of fake news and false viral social media postings. Michaelidou et al. (2011) argues that, the academic B2B literature has minimal references to the use of SNS and Big data and social media analytics as part of marketing strategy. However, the findings from Michaelidou et al. (2011) indicated that over $25 \%$ of B2B small medium enterprises (SME's) in the UK used SNS to achieve their marketing objectives with $44 \%$ of firms planning to increase their SNS budget. This suggests to an emerging acceptance of the significance of the use of SNS as part of B2B marketing. Researchers such as Mangold and Faulds (2009) suggest that social media tools such as blogs, rating websites, video and photosharing websites, podcasts and particularly SNS are new educational sources of online information around issues including products and brands. It can also help support and promote brands, including B2B brands and can thus help build and maintain relationships between B2B firms. Interactions encourage business customers to express their opinions in the form of feedback and create managerial knowledge that aids business activities like new product development or innovative marketing campaigns (Elkington \& Hammer, 2009). Companies that appoint other companies as business customers to serve other customers in remote territories find it very difficult to capture their feedback due to lack of access. Social media analytics brings managers of both firms together virtually and allows discussions about individual market trends and the singular requirements of business customers in those markets. Interactions with managers of customer firms provides deep insights into the rational requirements of business customer firms. Such information enables the provider firm to explore, understand and address the requirements of its customers. The literature also reports the ability of Participatory web to provide a collaborative environment which can benefit firms in many ways (Bughin, 2007; Constantinides \&
Fountain, 2007; Kim et al., 2009). For instance, it aids new ways of supporting efficient and effective knowledge creation with management and provides opportunities for reinventing business processes through improved initiatives such as employee engagement, reduced human involvement for less consumption of energy and reduction in the cost of human engagement (Mueller, Hutter, Fueller, \& Matzler, 2011). Giamanco and Gregoire (2012) posit that social media can be utilised in three key stages, consisting of prospecting (i.e., finding new leads), qualifying leads and managing relationships. While all these stages are of relevance, the latter stage of managing relationships from a sustainability perspective is paramount and vital. Supporting this, Brennan and Croft (2012) also reveal two key motives in organisations B2B social media participation. Firstly, B2B social media pioneers utilise social media in order to position themselves as 'thought leaders', in a bid to take a market driving role in the sector, secondly B2B social media use was mainly to build relationships with a range of stakeholder groups.

While the literature (Elkington, 2004) on sustainability recommends integration of different business functions for optimisation, research on web-based technologies explains the capability of Participatory web to provide a platform that addresses the need for integration of business functions that are inter-dependant (Mueller et al., 2011). Many of the marketing and operations models presented by researchers are grounded in the use of technology for efficient tracking of historical data that helps managers to improve their business performance (Dao et al., 2011; Gunasekaran \& Ngai, 2004; Visser, 2010). However, through the utilisation of Big data and Social media analytics, managers can also benefit from predictive capabilities that can help inform decision making and strategy (Wang et al., 2017). As per Visser (2010), firms that embrace the notion of technology-orientation will collaboratively find innovative methods of tackling challenges in order to become sustainable. A focus on electronic reporting and business transparency using social media tools can lead to sustainability through improved governance and enhanced institutional effectiveness (Lacy, Cooper, Hayward, \& Neuberger, 2010; Visser, 2010). Recent emergence of sustainability frameworks that recommend adoption of modern technology-based strategies for marketing and operations have been presented in Table 3 in the form of a taxonomy that reflects on the capability of web-based technologies to align these two prime activities of a firm with sustainability requirements.

The sustainability frameworks developed by Loeser, Erek, Schmidt, Zarnekow, and Kolbe (2011), Dao et al. (2011) and Visser (2010) have been applied by other researchers (Berthon, Pitt, Plangger, \& Shapiro, 2012; Sigala \& Marinidis, 2012) in the context of marketing and operational efficiency. In doing so, supporting the growth of a business with effective acquisition, analysis and dissemination of information as marketing initiatives. The context in which the frameworks have been applied helps support this research study which highlights the capabilities of web-based technologies such as Participatory web to attain business sustainability. Apart from this, as operations play an important role in acting upon information received and improving the overall efficiency of business management practices (Gunasekaran \& Ngai, 2004), Hagstrom, Hornby, and Farrell (2009) reported that organisations which lack state-of-the art infrastructure and technology related capabilities for managing business will remain stagnant in their growth. Growth based on technology and sustainability requires businesses to become radical in their business approach by shifting from a traditional to a systemic new approach in the adoption of business processes (Visser, 2010). Participatory web aids businesses to embrace this radical change in approach that will, in turn, enable them to achieve sustainability.

The current literature generally clarifies the differences between the two web generations rather than mapping them against any specific structure and highlights the use of the Participatory web to improve capability that can address the intensity of competition in the marketplace (Cormode \& Krishnamurthy, 2008; Levy, 2009; O'Reilly, 2007). Table 4 highlights the ability of businesses to work in participation with 
the social community and exploit the collective intelligence produced by users through Participatory web for achievement of sustainability related objectives. This table has been constructed with a specific focus, to build an understanding of business sustainability around Passive Web and Participatory web. While the authors are mindful that future generations of web-based technologies already exist, which are often referred to as Web 3.0 and so on, their development is arguably immature and still evolutionary (Aghaei, Nematbakhsh, \& Farsani, 2012; Kambil, 2008). Therefore, such web-based technologies are not specifically listed in the proposed taxonomy.

Table 4 classifies the key aspects of Participatory web methodically to categorise and present them in the form of a taxonomy based on the three dimensions of sustainability. The classification reflects on the progression of Passive web technologies to Participatory web technologies to map and compare them as drivers of sustainability. Overall, this taxonomy demonstrates that Participatory web is a significant tool for businesses by supporting the vital functions of marketing and operations and thus enabling the achievement of sustainability initiatives.

Participatory web tools also have a significant influence on supply chain in the B2B context which is key for business sustainability. According to Goh, Lee, He, and Tan (2007), the use of mashup techniques allows supply chain visibility and can thus allow buyers to monitor and assess the performance of suppliers. This can also be extended to enabling the use of data from other enterprise systems; for example, inventory data can be broadcasted using Really Simple Syndication (RSS) feeds thus enabling the manufacturer to be aware of inventory stock in real-time. Additionally, the use of supply chain applications as Software as Service (SaaS) enables easy sharing of information with all members of the supply chain (even worldwide in global companies), which in turn helps tackle the intricacies of B2B integration (Goh et al., 2007). Micro-blog platforms such as Twitter are key tools that allow quick dissemination of information that can be beneficial to businesses in saving costs (Fischer \& Reuber, 2011). According to Bunz (2009), the real-time stream of messages by microblogs is an important element of Participatory web. Blogs allow businesses to participate in a transparent but interactive format with stakeholders such as other businesses, enabling them to actively provide information and collect their feedback without meeting in person (Ergazakis, Mtaxiotis, \& Tsitsanis, 2011). Furthermore, free web-based office applications such as Google Docs have also proved able to unsettle the monopolistic advantages that some of the large organisations have had in the past against smaller businesses in terms of software licensing costs (Keller \& Hüsig, 2009. Keller and Hüsig (2009) use the case of the potential disruption caused by Google's web-based office applications to Microsoft's desktop office applications to explain how it was found that web applications can satisfy demand in established performance attributes. Furthermore, the leveraging of SaaS applications allows companies (particularly SME's) lacking a strong IT team to still benefit from the use of Participatory web to provide real-time support to companies. It also allows a degree to transparency which again promotes B2B integration (Goh et al., 2007).

\section{Research methodology}

A number of approaches can be taken to address the research questions of this research; however, it is widely understood that although quantitative research approach is well equipped at answering the where, what, who and when type of questions (Crabtree and Miller, 1999), it has limited success in sufficiently answering why or how a phenomenon happens (Denzin and Lincoln 2000; Silverman, 2000). Accordingly, qualitative research is more appropriate at providing important in depth and exploratory tools which are essential for gaining an in-depth insight into the processes of how and why a phenomenon occurs (Symon and Cassel, 1998). In addition, a further justification for the qualitative premise of this research is supported by Orlikowski and Gash (1994) who argue that qualitative approaches are ideal for 


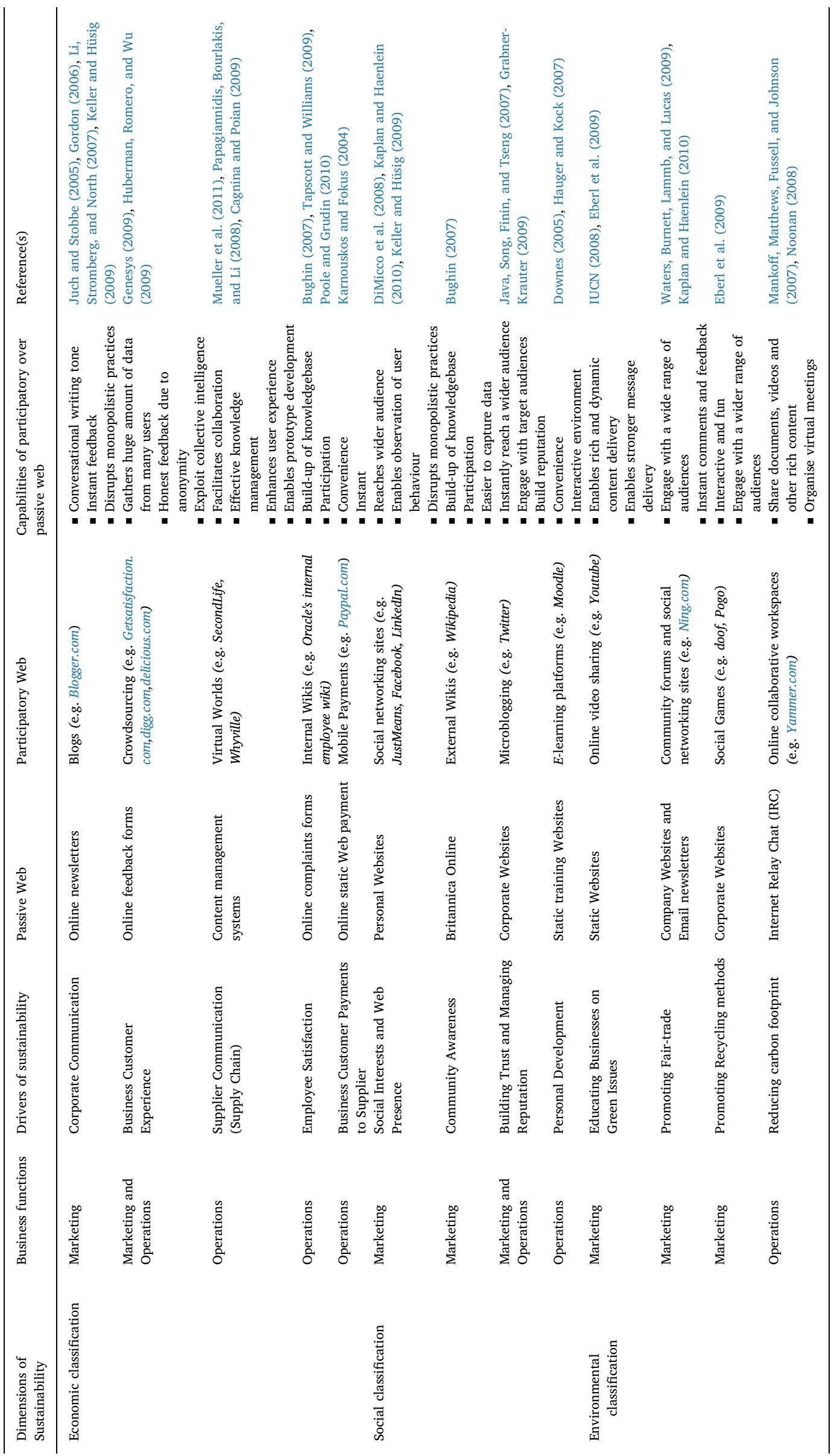


Table 5

Interview guide.

\begin{tabular}{|c|c|}
\hline Question types & Questions \\
\hline Participant demographics & $\begin{array}{l}\text { - Can you tell me a little bit about yourself? } \\
\text { - What is your name? } \\
\text { - What is your age? }\end{array}$ \\
\hline Educational background & $\begin{array}{l}\text { - What is the highest level of education you have received? } \\
\text { - List any other education or training relevant to the (position title) position. }\end{array}$ \\
\hline Employment background & $\begin{array}{l}\text { - Who is your present employer? } \\
\text { - What are your major responsibilities at (present/most recent job)? } \\
\text { - Discuss/determine skills and level of expertise related to this position }\end{array}$ \\
\hline Sustainability & $\begin{array}{l}\text { - How do you define sustainability? } \\
\text { - To what extent do you consider your organisation as being sustainably responsible? } \\
\text { - Do you consider your organisation as adopting a socially responsible approach to business? } \\
\text { - What factors do you consider when proposing a sustainability initiative? } \\
\text { - What tools do you use to facilitate your sustainability initiatives? }\end{array}$ \\
\hline Stakeholders & $\begin{array}{l}\text { - Who would you consider as your stakeholders? } \\
\text { - How important is it for you to engage with your stakeholders? } \\
\text { - Describe a time when you successfully communicated the effectiveness of sustainability initiatives. }\end{array}$ \\
\hline Big data analytics & $\begin{array}{l}\text { - Does your organisation use big data analytics? } \\
\text { - Can you define your organisations big data analytics strategy? } \\
\text { - What types of data do you use for your analytics? } \\
\text { - Have you explored or adopted open-source software for big data and analytics? } \\
\text { - Has your use of social media analytics affected your relationship with your stakeholders? If so, how? } \\
\text { - What big data tools do you use? } \\
\text { - How valuable is social media analytics for your organisation? } \\
\text { - How do you make sense of the insights from your big data analytics? } \\
\text { - Which type of data visualization tools do you use? } \\
\text { - Let's imagine the next } 7 \text { days, your organisation stops using big data analytics, what would be different? }\end{array}$ \\
\hline
\end{tabular}

extracting people's interpretations of technologies and their actions around them. Thus, rendering the qualitative nature of this research as being appropriate lenses to explore the complexities relating to B2B big data analytics and sustainability.

Thus, this research is exploratory in nature and adopts an inductive approach with the application of qualitative methods, involving a focused literature review and interviews. The literature review offered a snapshot of the landscape of web-based technology and sustainability research while the interviews of managers from large companies allowed the examination of causal dynamics across themes identified in the literature (Miles \& Huberman, 1994; Yin, 2011). Observations and semi structured interviews with the managers provided an understanding of the businesses, such as their origins, operations, and market and economic context. An open-ended approach (Yin, 2011) with semistructed questions was adopted for the interviews, which were conducted over 45 to 60 -min sessions spreading over a period of 2 weeks; this was important to ensure flexibility and arranging convenient times for the interviewees so that they can be free from any distractions. The interview guide used for conducting the interviews is included in Table 5, however additional follow-up questions were also used to get respondents to elaborate on ambiguous or incomplete answers. Care was also taken to reduce bias through refraining as much as possible from asking leading questions (Miles and Huberman, 1994).

A total of nine interviews took place during this time with sustainability and technology management managers from large companies. A breakdown of the participant profiles is highlighted in Table 6 in order to provide an overview of the research sample. It is noted that interviews should continue until additional interviews fail to provide any new insights into the study area (Taylor \& Bogdan, 1998), also referred to as the point of theoretical saturation (Glaser \& Strauss, 1967). Therefore, interviewing terminated following the ninth research participant, as a result of continuous repetition of themes. Access to interviewees was arranged due to the personal connections the research team had with the companies. All interviewees were fully informed about the purpose of the interviews and steps were taken to put the interviewees at ease during the interviews so that a two-way, open communications climate existed (Shaughnessy \& Zechmeister, 1985). Detailed notes were taken electronically during each interview followed by checking, organisation and producing a narrative report of each of the interviews. The relevant sections of the transcripts were then passed on to the interviewees and discussed in short 20-30-min meetings to ensure that the information recorded is an accurate representation of what was discussed during the interviews (Yin, 2011). This process resulted in minor edits to the transcripts to improve clarity. Subsequently, the data analysis was done using a thematic analysis process (Boyatzis, 1998) adopting a manual coding approach and using triple bottom line theory as a conceptual lens which allowed to explore similar dynamics and meanings across the interviewees (Mingers, Mutch,

Table 6

Participant profile table.

\begin{tabular}{|c|c|c|c|c|c|}
\hline Organisation type & Industry & Job role & Gender & Age group & Work experience \\
\hline SME & IT & IT Manager & Male & $25-45$ years & 7 years \\
\hline MNE & IT Consulting & CSR Consultant & Male & $30-45$ years & 11 years \\
\hline SME & Web development & Web Manager & Female & $30-45$ years & 5 years \\
\hline MNE & Energy & CSR Marketing Manager & Male & $30-45$ years & 9 years \\
\hline MNE & Management consultancy & Sustainability Manager & Male & $30-45$ years & 15 years \\
\hline SME & IT & B2B Operations and Relationship Manager & Female & $25-45$ years & 5 years \\
\hline MNE & IT & Operations Manager & Male & $30-45$ years & 21 years \\
\hline MNE & IT & Digital Marketing Manager & Male & $30-45$ years & 16 years \\
\hline SME & IT & Sustainability Manager & Female & $30-45$ years & 10 years \\
\hline
\end{tabular}


Table 7

Qualitative thematic analysis summary.

\begin{tabular}{|c|c|c|}
\hline Themes and sub-themes & Brief description of themes and sub-themes & $\begin{array}{l}\text { Frequency of reference to the } \\
\text { sub-themes }\end{array}$ \\
\hline $360^{\circ}$ transparency & $\begin{array}{l}\text { This theme emerged from the data which highlighted the importance placed by managers on two-way } \\
\text { transparency resulting from the use of big data analytics. }\end{array}$ & \\
\hline a) Organisational integrity & $\begin{array}{l}\text { The managers felt tools such as data mining allowed them to address the needs of their stakeholders and } \\
\text { responsibly respond to queries, thus enhancing and upholding their corporate }\end{array}$ & 8 \\
\hline b) Stakeholder loyalty & $\begin{array}{l}\text { The managers highlighted how social media analytics enabled them to gauge stakeholder loyalty, } \\
\text { particularly towards new sustainability initiatives }\end{array}$ & 11 \\
\hline Sustainability presence & $\begin{array}{l}\text { The theme refers to how the managers were inclined to use big data analytics in order to have active } \\
\text { sustainability presence in the virtual space }\end{array}$ & \\
\hline a) Driving change & $\begin{array}{l}\text { A movement from reactive to proactive analytics, whereby the organisations themselves were the drivers } \\
\text { of their sustainability initiatives and thus aimed to gain influencer status }\end{array}$ & 8 \\
\hline b) Managing societal expectations & $\begin{array}{l}\text { The managers emphasised how the use of analytics, particularly on social media allowed them to actively } \\
\text { promote and align themselves against other key stakeholders }\end{array}$ & 5 \\
\hline c) Competition & $\begin{array}{l}\text { Managers highlighted the urgency of marketing and responding to their sustainable initiatives online, } \\
\text { particularly in response to competitors }\end{array}$ & 6 \\
\hline Detecting opportunities & $\begin{array}{l}\text { This theme largely concerned all the opportunities which surfaced as a result of the actively engaging with } \\
\text { big data analytics }\end{array}$ & \\
\hline a) Traffic to leads & $\begin{array}{l}\text { Big data analytics were being operationalised by managers in order convert 'social media traffic' to leads } \\
\text { for sustainability initiatives as well as other business functions }\end{array}$ & 9 \\
\hline b) Strengthening collaboration & $\begin{array}{l}\text { Sustainability driven analytics and social media campaigns were seen as positively impacting and } \\
\text { strengthening existing collaborations between stakeholders }\end{array}$ & 12 \\
\hline c) Change of perceptions & $\begin{array}{l}\text { MNE managers highlighted that following their sustainability activities online, their organisations at some } \\
\text { point experienced a reduction in impulsive negative statements about their organisation }\end{array}$ & 5 \\
\hline Minimising risks & This theme emphasised the increasing role of analytics in minimising risks and threats to organisations & \\
\hline a) Flagging misinformation & $\begin{array}{l}\text { Managers were able to actively monitor social media posting regarding their organisations, with the tools } \\
\text { providing early alerts on emerging risks, and assisting in identifying ways to shape social network } \\
\text { narratives. }\end{array}$ & 8 \\
\hline b) Risk assessment & $\begin{array}{l}\text { The use of analytical tools such as RepRisk allowed managers to track whether organisations may be } \\
\text { associated to issues such as child labour, pollution, human rights abuses etc. Managers largely used this } \\
\text { function to monitor existing stakeholders or when in the process of building relationships with new } \\
\text { business partners }\end{array}$ & 5 \\
\hline c) Myth busting & $\begin{array}{l}\text { Having the ability to respond to customers queries, unconfirmed statements and tales, which without } \\
\text { social media analytics would otherwise go uncontested }\end{array}$ & 7 \\
\hline
\end{tabular}

\& Willcocks, 2013; Yin, 2011).

\section{Analysis and discussions}

In line with recommendations by Miles and Huberman (1994), thematic analysis can assist in generating meanings from data. Given the inductive nature of this research, thematic analysis was used to facilitate in addressing the varying questions posed by the researchers and in order to generate analytical insights relating to the underlying meaning in the qualitative data. Thematic analysis was considered appropriate for this research as it provide a rich and highly detailed, yet multifaceted accounts of the data (Braun and Clarke, 2006), therefore allowing for many themes of the research to be interpreted (Boyatzis, 1998). Meanings can surface from the data through pattern discovery, relationships, themes, and ideas in the qualitative data that comprise both interdisciplinary and multidisciplinary literature. The initial emerging themes were noted across all the research participants, which highlighted the key aspects of each account. Data which shared similar meanings were subsequently categorised, eventually leading to the identification of broader themes across each of the data sets, as highlighted in the analysis summary provided in Table 7.

Through this process of qualitative thematic analysis, the superordinate themes of ' $360^{\circ}$ transparency', 'Sustainability presence', 'Detecting opportunities' and 'Minimising risks' were derived from the data, thus reflecting managers perceptions and use of big data and social media analytics from a sustainability context. For the ' $360^{\circ}$ transparency' theme, the authors identified initial codes emerging from the data, which led to the sub-themes of 'organisational integrity' and 'stakeholder loyalty' being identified. Both of these sub-themes were regularly picked up in the data and related to managers perceptions of a two-way transparency resulting from B2B sustainability. The emphasis placed by the managers was on the transparency offered to stakeholders relating to their organisations and how the insights from the analytics also allowed for stakeholder transparency, as reflected through their interactions on social media platforms. The authors also categorised the subthemes of 'driving change', 'managing societal expectations' and 'competition' as the subordinate theme of 'sustainability presence'. This theme largely related to how the managers utilised big data analytics to drive change, engage with stakeholders and outperform potential competitors in their sustainability activities within the virtual space, across various social media platforms. The 'Detecting opportunities' theme was made up of 'traffic to leads', 'strengthening collaboration' and 'change of perceptions' sub-themes, which centred on the opportunities the managers felt they were able to leverage through their B2B sustainability activities. The remaining theme of 'Minimising risk' theme, which consisted of 'flagging misinformation', 'risk assessment' and 'myth busting' sub-themes were strongly expressed by managers and highlighted the increasingly proactive role of big data analytics in countered risks and responding at a fast rate. These key themes and particularly the analytical tools and techniques which underpin these themes are discussed in greater detail in the following section.

\section{1. 'Communicating sustainability is just as important as doing it' - stakeholder engagement}

The participants emphasised the importance of acknowledging the impact of interactions and how the use of the participatory web was a key facilitator for stakeholder engagement. One of the practitioners spoke of issues related to sustainability and need for interaction, collaboration, participation or experience in following words:

"We face many challenges in business. One of the challenges we face every day is working towards sustainability, which is very complex. 
First, not everyone understands what should be done and second none of us can do it alone. So, to recognise what should be our plan or strategy so that we don't harm the planet, people or profit. Therefore, interactions become very important. Another point is that it is very difficult to know perspective of all the stakeholders. Web based interaction opportunities help us to identify where we can go wrong, particularly through live data-driven insights After identifying a sensitive action point in terms of sustainability, we try to deal with is to collaborate with each other to make sure that at no stage in our value delivery chain, anyone is getting harmed in any way."

The underlying role of interactions between the organisation and all the relevant stakeholders is emphasised here. It is clear from this statement, that the manager is highly reliant on web-based interactions and analytics in order to interact with key stakeholders. Emphasis is placed on trying to identify the perspectives of all stakeholders and how the use of analytics enables the organisation to gain personalised insights into the interests of their stakeholders. Stone (2009) adopts a social approach to recommending the use of web-based technologies like Participatory web for engaging, listening and empathising by understanding needs and responding in an appropriate manner. Social media provides opportunities of fulfillment based on economic realisation through identification of needs and building long-term relationships based on social empathy and trust (Grabner-Krauter, 2009). Companies in a B2B setup are investing in social media analytics to benefit from their ability to support their need to be competitive and use minimum resources for engaging with a larger audience (Tucker, 2011; Visser, 2010). Social media tools provide listening, learning and support opportunities to managers in serving their stakeholders without building physical infrastructure, (Elkington \& Hammer, 2009; GarciaCrespo, Colomo-Palacios, Gomez-Berbis, \& Ruiz-Mezcua, 2010) while also allowing for managers to keep an eye on trends across the three domains of sustainability. The efficient use of participatory web technologies such as Big data and social media analytics to fulfil infrastructural requirement aids environmental sustainability that drives the longevity of a business in a competitive business world (Genesys, 2009). Interactive virtual platforms are blogs (e.g. Blogger) and micro-blogs (e.g. Twitter), SNS (e.g. Facebook and LinkedIn) and other initiatives like wikis (e.g. Wikipedia), video-sharing (e.g. YouTube), picturesharing (e.g. Flickr), social bookmarking (e.g. Digg) all provide consumer-generated data, which through the effective utilisation of Big data and social media analytics provides knowledge building opportunities and importantly maximize the customer experience. The proactive use of Social media analytics allows organisations to learn from customers and improve products and services accordingly.

\section{2. 'Understanding how our stakeholders feel about us is invaluable...!' - sentiment analysis}

It is evident from the data analysis that social media not only provides interactive communications and the opportunity to build networks, which have been found suitable for business by managers handling marketing and operations, but also through Big data and social media analytics, it allows organisations to gain insights into realtime consumer choices, intentions and sentiments. The role of sentiments analysis from a B2B context is evident when a manager working in an SME provided explanation of the responsiveness ability achieved through Participatory web in following words:

"Our products are highly customer-oriented. Previously, we were using web to communicate to our customers. But now, with the help of sentiment analysis we are able to know the reaction of customers to our products and also our actions. This analytics technique allows us to monitor social media conversations concerning our organisation's activities and provides alerts on customer feedback, specifically whether they are posting positively or negatively. These capabilities of social media have helped us become more responsive to the requirements of stakeholders and also increased consciousness of our managers towards issues related to sustainability."

It is evident that by utilising sentiment analysis, this manager has the ability to understand 'how his customers feel', allowing him to react according to their needs, which given the fashion-conscious consumer context, can prove to be highly advantageous. More specifically, the manager emphasizes how sentiment analysis provides not only useful information, but highly personalised insights into the feelings of their stakeholders, thus offering valuable information and feedback. The manager further outlines:

"It's great, as the more accurate the insights are into understanding our stakeholder perceptions, includes partners and competitors, not just our customers, the more actionable the information becomes for us".

Sentiment analysis in this case helps this B2B operations manager identify their engagement level with their customers and importantly, with other key stakeholders too. However, alternatively another manager outlines some challenges associated with utilising such techniques. She states:

'I always ask myself whether tools like sentiment insights are a true reflection? I mean, we still have to fact-check what the analysis is suggesting, because I don't think it picks up sarcasm, or ambiguous statements?... nonetheless, it is still useful to gauge opinions of people'.

It is clear that this manager takes a more cautious approach when utilising analytical techniques such as sentiment analysis, particularly given how nuanced posts may be on social media. However, generally it was accepted that big data analytics, through techniques such as sentiment analysis was increasingly being used by the managers, as a means to loosely identify perceptions of their stakeholders relating to their organisation. This is further highlighted when a manager stated:

'Sentiment analysis is really useful for us, if we have a decent volume of feedback, we can simple drill down to 'most happy' or 'least happy' responses. It really helps us prioritise our actions or simply tells us we're doing something right!'

It is clear that techniques such as sentiment analysis are important for managers, as it allows them to capture how their stakeholders feel at any given time, thus allowing them to take appropriate action in response to stakeholder sentiments. B2B organisations pursuing sustainability initiatives can greatly benefit from sentiment analysis, as this technique enables them to attribute sentiments to specific sustainable products, services or activities and track perceptions' relating to them. Therefore, sentiments and trends can be compared between stakeholders and across agencies and organisations who may also be advocates of similar sustainability causes.

\section{3. 'What people are saying is important... but who is saying it is more important' - social network analysis}

Identifying the most powerful influencers is always a challenge for organisations. Important influencers are those who are able to shape public opinion and in essence the entire realm of conversation from social media contexts. A director of one of the SME firms that uses social network analytics to serve its customers, stated that:

"After we started using Social network analytics, business became slightly easier for us because we could instantly connect with customer, and the speed at which we communicated or interacted with them customers, reflected on transparency in our business practices. Due to which, customers, vendors and suppliers felt more confident in dealing with us. The analytics not only allow us to communicate with our existing customers, but helps us identify who else we need 


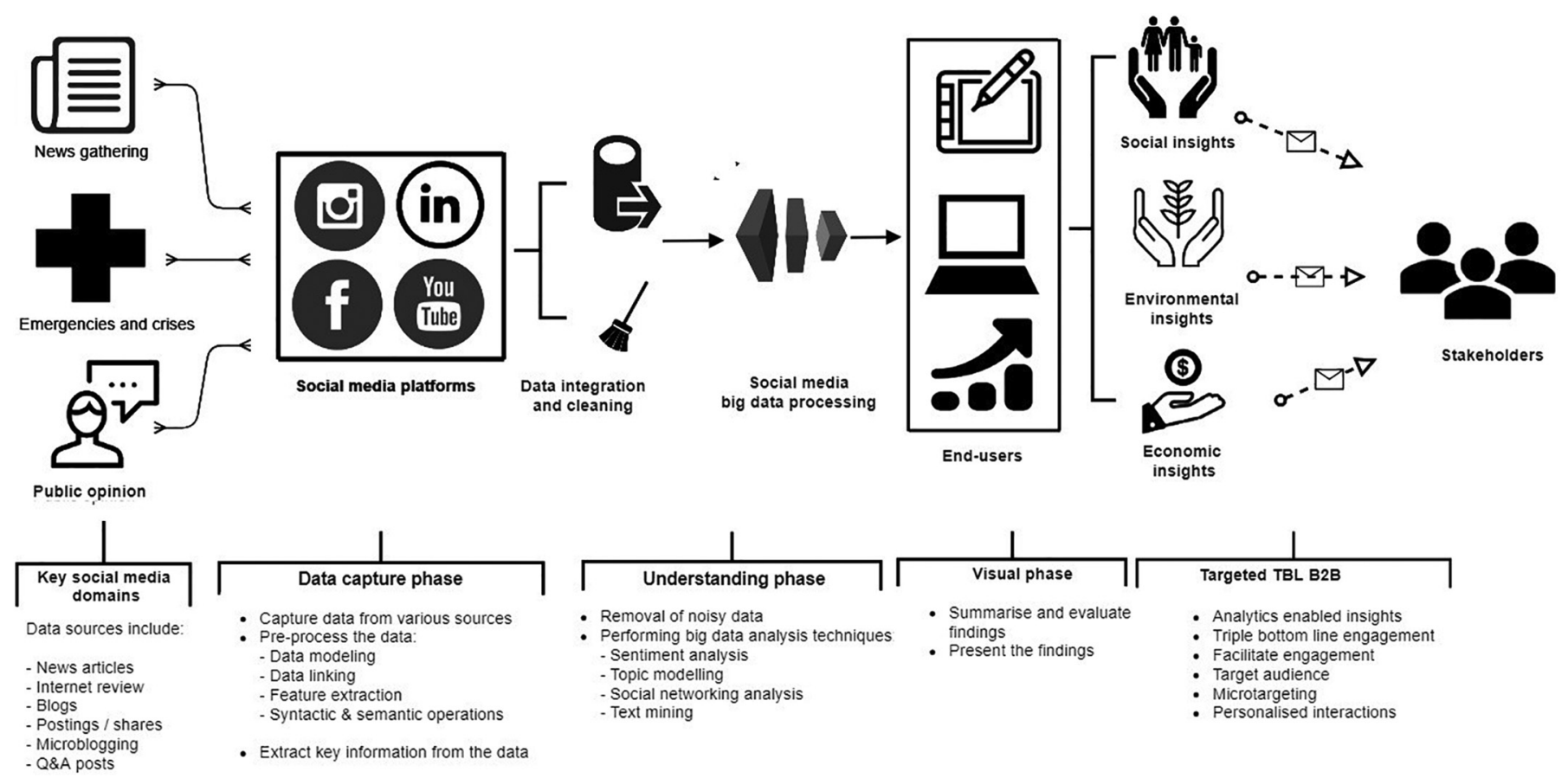

Fig. 1. B2B Social media data analytics process (source: Authors).

to target".

The Social network analysis technique is seen here as assisting in monitoring business activity and identifying key influencers across social media platforms, thus providing granular insights into the nature of the interaction between stakeholders and particular business offerings. This analytical technique as highlighted by the director of the SME can prove valuable in identifying potential customers who may be directly or indirectly linked to existing customers, thus providing marketing insights. The director went on to also state:

"It is important to familiarise yourself with your customers, especially those who influence your customers, as they tend to be key in spreading information on social media".

The technique allows organisations who advocate environmentally sustainable principles to gain insights into the nature of conversations, level of acceptance or reluctance they are face by sieving through social media platforms to better understand who the influencers' are in their space and how their brand is positioned relative to others in the market.

Participatory web tools also help harness collective intelligence through text mining to better understand demand patterns which again would assist in the operational aspect of the company thus driving sustainability (Goh et al., 2007). Text involves extracting information from various types of unstructured contents, such as text, videos and images, given that social media platforms are heavily populated with such content, text mining has become a highly valued technique for analysing social media content (Ghani et al., 2018). A senior manager outlined:

"The ability to capture information from videos and other unstructured forms at relative ease is invaluable, as it allows us to stay on top of the trends and the perceptions and feelings of our customers."

It is obvious that this additional layer of social analytics enables organisations to meaningfully capture large volumes of unstructured data which enhances their understanding by providing early insights into what customers are thinking, thus allowing them to better engage with their stakeholders marketing message, while also providing transparency. This technique can also be invaluable for B2B customer engagement, as text mining enables an organisation to combine appropriate structured data with large sets of unstructured text data, to predict stakeholder perceptions as well as purchasing behaviour, thus allowing them to satisfy customer and stakeholder needs and requirements in a timely and efficient manner.

6.4. 'We can now spot it from miles away and instantly respond!' - myth busting

In addition to the benefits of real-time insights and customer engagements, social media analytics also provided managers with the opportunity to respond to incorrect information posted on social media about their organisations. Analytical tools allow organisations to identify and counter misinformation and similar threats in real-time. This was also expressed by a sustainability manager of a SME, who highlighted:

"It good, you know it allows you to bust myths before they go viral. The ability to respond in real-time gives me assurance, especially if you're having to respond to negativity about your organisation".

Use of such tools supports marketing functions by making the firm approachable to its business customers and by providing opportunities of engagement and interactions with them in a format that evokes expression of emotions and motivation (Cormode \& Krishnamurthy, 2008). Although the SME manager did not explicitly refer to 'fake news', it is evident that such utility of social media analytics facilitates engagement and exchange of information between participants (Adebanjo \& Michaelides, 2010; Kim et al., 2009). Additionally, a CSR marketing manager for a large MNE highlighted: 'Our analytic tools allow us to police our social media platforms, for an organisation like us, reputation is extremely important. So, by getting instant notifications of who is saying what about us, allows us to safeguard our reputation' A sustainability manager at a SME also expressed similar sentiment: 'It really helps, just how spam emails are picked up, our analytics tools in some way perform similar functions, but across social media platforms, posts can get flagged, allowing use to respond if required'. This provides insights into the underlying motives of managers for utilising big data and social media analytics, as a means of 
protecting their reputation and overcoming threats. Overall, the key stages of the social media analytics process consists of capturing, understanding and presentation phases. The aforementioned big data analytics techniques highlighted in the analysis would principally be utilised in the understanding phase, as highlighted in Fig. 1.

\section{Awareness of key challenges}

It is also important for managers to be aware of some of the challenges of the use of Big data and social media analytics by B2B sector companies. This is an important consideration as these challenges need to be carefully considered when planning and implementing innovation-related managerial approaches carried out by means of Participatory web tools. The use of partially social media-based approaches such as crowdsourcing may be challenging in the B2B context (Karkkainen, Jussila, \& Vaisanen, 2010). In a B2C setting, individual customers are motivated to participate using social media, with significant motivators being recognition, self-esteem and a sense of community. This although prevalent, is unlikely to manifest in the same magnitude in professional customers (B2B sector) who may not be as amenable to the use of Participatory web tools such as social mediabased tools for interactions (Karkkainen et al., 2010). A lack of training and support in the use of Participatory web tools can be a significant barrier in the use of these technologies by companies in a B2B environment. A lack of familiarity with systems and the lack of technical skills required in operation of such tools are significant factors that may prevent SME's using Participatory web-based tools (Michaelidou et al., 2011). The challenges discussed should not discourage managers in B2B companies from adopting Participatory web tools. Instead, they should help provide an insight into the importance of the use of the appropriate Participatory web applications in keeping with individual needs to help operational and marketing functions. In doing so, helping companies achieve business sustainability.

\section{Research contributions, limitations and future research}

Key findings from both Dao et al. (2011) and Sheth, Sethia, and Srinivas (2011) suggest that when considering stakeholder issues, business activities should be embedded in sustainability principles particularly by marketing and operations. Therefore, it is important for managers to consider stakeholder recommendations and involve them in orientation of these two important and different business functions towards sustainability for superior performance of their business (Gupta \& Kumar, 2013). However, it is also important to understand the strengths and weaknesses of technology to facilitate achievement of these business objectives. The following sections present the research contributions (both theoretical and practical) and limitations of the research findings and provide suggestions to future researchers.

\subsection{Theoretical contributions}

The developed taxonomies present different features of Participatory web, and social media analytics while a broad category of its applications is constantly developing. Therefore, the authors anticipate that applications within these categories will also constantly continue to grow. Furthermore, this research builds on existing B2B sustainability research (Liu \& Zhang, 2017; Song et al., 2016; Song et al., 2017; Zhang et al., 2017), and answers the call of recent studies (Bughin et al., 2010; Dubey et al., 2017; Jeble et al., 2018) by offering insights into the B2B sustainability dyad through a stronger empirical and theoretical underpinning. This research has also mapped key big data analytical techniques from the extant literature and provided an conceptualization of B2B Social media data analytics process (Fig. 1), which can prove to be beneficial for future studies exploring B2B sustainability and analytics. The exploratory nature of this research supports the building of a theoretical foundation that can be used by scholars for developing indicators of the relationship between ICT and sustainability context. First, the study findings indicate that current B2B practices will require managers to be proactive in choosing the most upto-date and appropriate applications to meet their business and stakeholder requirements. Second, the implications of the research findings are in line with the findings of Osimo (2008) who recommended use of Participatory web applications in the public domain and particularly in the context of electronic government (e-Government). The authors use their findings and the recommendations of researchers such as Osimo (2008) to recommend adoption of Participatory web by businesses in a B2B context to maximize stakeholder engagement and enablement. Overall, the study demonstrates how Participatory web can drive companies especially in a B2B setting to use a Participatory web based dynamic business environment that allows exchange of information and creates opportunities for marketing and operations through knowledge building and dispersion related activities.

\subsection{Practical contributions}

This research highlights how Big data and social media analytics have been reported to enable small companies to upset the monopolistic advantages that some companies have had in the past by researchers such as Keller and Hüsig (2009). The strong effect of networks on the lead players in the market is discussed in this study to reflect on how managers should use Participatory web to give incumbents time to forecast and drive their actions towards sustainability initiatives. The study posits that managers in a B2B company need to be aware of the challenges of adopting the appropriate Participatory web tools in keeping with individual needs to help operational and marketing functions in order to attain business sustainability. Furthermore, considering the possible bias of potential web users from the technology non-friendly community, this research proposes that firms should firstly identify the individual dimensions of sustainability that might influence awareness of stakeholders about these initiatives. Subsequently they then need to communicate its value to those particular stakeholder communities. Finally, the study also reflects on the literature to recommend that managers should keep up with progressive technologies Cloud Computing, Big Data, Internet of Things (IoT) to address the challenges of a competitive market (Jones, Irani, Sivarajah, \& Love, 2017; Sivarajah, Irani, \& Weerakkody, 2015; Sivarajah, Kamal, Irani, \& Weerakkody, 2017; Tredinnick, 2006).

It must also be noted that this research can change the way in which managers utilise data within B2B contexts. By highlighting the benefits of implementing big data analytics from a sustainability perspective can help promote sustainability initiatives for other organisations, who may be using big data analytics, but for decision making and other operational functions, other than to pursuit sustainability initiatives. Thus, this research can benefit the society as the findings indicate how sustainability can be enhanced by organiations as a result of B2B big data analytics, thus ultimately having a positive impact on the society.

\subsection{Research limitations and future research}

As with many studies, this research also has some limitations. While the taxonomies provide a theoretical structure to the existing knowledge about Participatory web, they lack empirical evidence which is the main limitation of this research. Despite the important contributions of Participatory web-based technologies towards improvement of the work environment and business efficiency, its inability to reduce carbon emissions or waste disposal has been reported by authors such as Jenkin, Webster, and McShane (2011). An increase in the number of data centres required by businesses for the use of web-based technologies adds to the carbon footprint and leads to an increase in environmental concerns by some stakeholders (McKenna, 2008). The authors anticipate that future researchers will be able to establish the argument of this research using empirical data. Researchers could also 
study the longevity of the impact of Participatory web in being able to disrupt the negative effects of a business adopting monopolistic practices, as well as looking into the sustainability orientation of those practices. Furthermore, as future generations of web-based applications emerge, these can be used to develop more comprehensive taxonomies similar to Table 4 by including comparisons of all the web generations. Stakeholder issues like reliability, accuracy and authority of access to information have also been raised by researchers like Huijboom et al. (2009) and the authors are also aware that Participatory web technologies pose threats such as security problems, issues of privacy, risk of information overload and poor quality of content shared by public users (ibid). Therefore, future researchers studying the use of Participatory web technologies in a B2B context to facilitate sustainability should be aware of these issues. It is also worth noting that generalizability is often a concern in studies. Accordingly, the demographic of this research sample may also be considered a limitation. As a means to circumvent noise generated by industry variances, the research sample was deliberately drawn from the IT industry. Furthermore, in order to overcome inferences resulting from personal background differences, the research participants who held similar managerial responsibilities in their organisations were selected. Therefore, we acknowledge that the sample may limit the generalisability of the research findings. We accept that this research does not allow for broader generalisation, and that the findings should be applied to other contexts with caution and that further investigations which explore more industries, countries and participants from divergent background are required to evaluate the wider implications of the big data analytics and sustainability dyad from B2B context. Moreover, while the sustainability benefits of Big data and social media analytics are beyond dispute, recent legislation, namely General Data Protection Regulation, 2018 (GDPR) have not been considered in the context of B2B. For a more holistic overview, insights into the misuse of social media and the dangers of misusing Big data and social media analytics may be a direction for future research.

\section{Conclusions}

This study highlights the relationship between two important but challenging domains of web-based technology (Participatory web) and sustainability in a B2B environment. Its exploratory nature supports the building of a theoretical foundation that can be used by other researchers for developing indicators of the relationship between these two domains; web-based systems and sustainability. This paper has sought to contribute to the literature by offering four novel classifications that underpin business sustainability. The developed taxonomies offer an insight into: (1) models associated with business sustainability; (2) ICT enablers for business sustainability; (3) models of business sustainability that leverage new technologies and Participatory web and, (4) the capabilities of Participatory web for business sustainability.

Additionally, it identifies two important interrelated business functions that are closely linked to the orientation of a business to sustainability i.e. operations and marketing. The findings reflect upon the use of Big data and social media analytics, namely Sentiment analysis, Social network analysis, Text mining and Topic modelling techniques to highlight and benefit from the interrelationships between these business functions and constructs. Hence, this may be considered as a distinct way of attaining sustainability. The use of Participatory web for integrating marketing and operations related activities as sustainability initiatives have been explained by mapping the capabilities of Participatory web technologies against these business functions and the three dimensions of sustainability in the form of different taxonomies. Considerable research is available that explains the two functions individually. However, comparatively fewer efforts have been made to explore the capabilities of Participatory and intelligent web to integrate these two functions. The key conclusions of this research can be explained around the following themes. First, there is an emerging trend of leveraging modern web-based technologies such as Big data and social media analytics highlights the shift in traditional business practices to sustainability driven business practices based on technology-oriented business approaches. Second, Big data and social media analytics generate opportunities for companies in a B2B domain to engage with two important functions of a business i.e. marketing and operations in a way that can accomplish the sustainability objectives of a firm. Finally, Big data and social media analytics can enable a B2B company to become profitable through strategic operations carried out for the achievement of the social, environmental and economic agendas of stakeholders with optimum use of infrastructure and natural resources. Particularly as Big data and social media analytics allows the organisation to know their customer base on a more emotional level which not only enhances the service proposition, but also enables a more focused and targeted collaboration.

\section{References}

Adebanjo, D., \& Michaelides, R. (2010). Analysis of participatory web enabled e-clusters: A case study. Technovation, 30(4), 238-248.

Aghaei, S., Nematbakhsh, M. A., \& Farsani, H. K. (2012). Evolution of the world wide web: From web 1.0 to web 4.0. International Journal of Web \& Semantic Technology, 3(1), 1-10.

Ali, M., \& Bailur, S. (2007). "The challenge of 'Sustainability'" in ICT4D - Is bricolage the answer? Proceedings of the 9th international conference on social implications of computers in developing countries (pp. 10). Sao Paulo, Brazil: International Federation for Information Processing.

Allenby, B. (2011). Thoughts on industrial ecology, emerging technologies and sustainability science. Sustainability Science, 6, 119-122.

Andriof, J., Waddock, S., Husted, B., \& Rahman, S. (2002). Unfolding stakeholder thinking: Theory, responsibility and engagement. Sheffield: Greenleag Publishing9-16.

Avgerou, C. (2008). Information systems in developing countries: A critical research review. Journal of Information Technology, 23, 143-146.

Azapagic, A. (2003). Systems approach to corporate sustainability. Process Safety and Environmental Protection, 81(5), 303-316.

Berthon, P. R., Pitt, L. F., Plangger, K., \& Shapiro, D. (2012). Marketing meets participatory web, social media, and creative consumers: Implications for international marketing strategy. Business Horizons, 55(3), 261-271.

Bonchi, F., Castillo, C., Gionis, A., \& Jaimes, A. (2011). Social network analysis and mining for business applications. ACM Transactions on Intelligent Systems and Technology, 2(3).

Boyatzis, R. E. (1998). Transforming qualitative information: Thematic analysis and code development. Sage.

Braun, V., \& Clarke, V. (2006). Using thematic analysis in psychology. Qualitative Research in Psychology, 3(2), 77-101 ISSN 1478-0887.

Brennan, R., \& Croft, R. (2012). The use of social media in B2B marketing and branding: An exploratory study. Journal of Customer Behaviour, 11(2), 101-115.

Briscoe, G., \& Marinos, A. (2009). Digital ecosystems in the clouds: Towards community cloud computing. Digital ecosystems and technologies, 2009 (pp. 103). Istanbul: IEEE DEST '09. 3rd IEEE international conference.

Bughin, J., Chui, M., \& Manyika, J. (2010). Clouds, big data, and smart assets: Ten techenabled business trends to watch. The McKinsey Quarterly, 56(1), 75-86.

Bughin, J. R. (2007). How companies can make the Most of user-generated content (The McKinsey qQuarterly ed.). Brussels: McKinsey and Company.

Bunz, M. (2009). 8/12/2009-last update. Dell makes $\$ 6.5 \mathrm{~m}$ from twitter sales $\mid$ media $\mid$. guardian.co.uk [Homepage of Guardian], [Online]. Available: http://www.guardian. co.uk/media/pda/2009/dec/08/socialnetworking-digital-media (2011, 10/11/ 2011)

Cagnina, M. R., \& Poian, M. (2009). Beyond e-business models: The road to virtual worlds. Electronic Commerce Research, 9(1-2), 49-75.

Castillo, C., Mendoza, M., \& Poblete, B. (2011). Information credibility on twitter. Proceedings of the 20th international conference on World wide web, WWW '11 (pp. 675684). New York, NY, USA: ACM.

Chabowski, B. R., Mena, A. J., \& Gozalez-Pandron, T. L. (2011). The structure of sustainability research in marketing, 1958-2008: A basis for future research opportunities. Journal of the Academy of Marketing Science, 39(1), 55-70.

Connelly, B. L., Ketchen, D. J., \& Slater, S. F. (2011). Towards a 'theoretical toolbox' for sustainability research in marketing. Journal of the Academy of Marketing Science, 39(1), 86-100.

Constantinides, E., \& Fountain, J. S. (2007). Participatory web: Conceptual foundations and marketing issues. Journal of Direct Data and Digital Marketing Practice, 9(3), $231-244$.

Cooke, M., \& Buckley, N. (2007). Participatory web, social networks and the future of market research. International Journal of Market Research, 50(2), 267-292.

Cormode, G., \& Krishnamurthy, B. (2008). Key differences between web 1.0 and participatory web. First Monday Peer-Reviewed Journal on the Internet, 13(6), 1-30.

Crabtree, B., \& Miller, W. (1999). Doing Qualitative Research (2nd edn.). Thousand Oaks, California: Sage18-20.

Crittenden, V. L., Crittenden, W. F., Ferrell, L. K., Ferrell, O. C., \& Pinney, C. C. (2011). Market-oriented sustainability: A conceptual framework and propositions. Journal of the Academy of Marketing Science, 39(1), 71-85. 
Dao, V., Langella, I., \& Carbo, J. (2011). From green to sustainability: Information technology and an integrated sustainability framework. The Journal of Strategic Information Systems, 20(1), 63-79.

Denzin, N., \& Lincoln, Y. (2000). The Discipline and Practice of Qualitative Research. In N. K. Denzin, \& Y. S. Lincoln (Eds.). Handbook of Qualitative Research (pp. 1-32). Thousand Oaks: Sage.

DiMicco, J., Millen, D. R., Geyer, W., Dugan, C., Brownholtz, B., \& Muller, M. (2008). Motivations for social networking at work. Proceedings of the 2008 ACM conference on computer supported cooperative work (pp. 711). New York, USA: ACM.

Downes, S. (2005). E-learning 2.0. Canada: eLearn Magazine.

Dubey, R., Gunasekaran, A., Childe, S. J., Papadopoulos, T., Luo, Z., Wamba, S. F., \& Roubaud, D. (2017). Can big data and predictive analytics improve social and environmental sustainability? Technological Forecasting and Social Change. https://doi. org/10.1016/j.techfore.2017.06.020.

Dunn, J. R., \& Varano, M. W. (1999). Leveraging web-based information systems. Information Systems Managment, 16(4), 1-10.

Dyllick, T., \& Hockerts, K. (2002). Beyond the business case for corporate sustainability. Business Strategy and the Environment, 11(2), 130-141.

Eberl, J., Flannery, M., Queen, N., McGrath, K., Guyer, R., Dennings, K., \& Estes, C. (2009). Use of new media to cause recycling behavior change. Environmental assistance office (EAO) infrastructure, design, environment, and sustainability (IDEAS) center North Carolina, USA: UNC Charlotte.

Elkington, J. (1998). Cannibals with forks: The triple bottom line of sustainability. Gabriola Island, BC: New Society Publishers.

Elkington, J. (2004). Enter the triple bottom line. In A. Henriques, \& J. Richardson (Eds.). The triple bottom line, does it all add up?: Assessing the sustainability of business and CSR (pp. 1-16). London: Earthscan Ltd.

Elkington, J., \& Hammer, A. (2009). 04/07/2009-last update. Where next with social media? (Época Negócios) - Library | SustainAbility. [Homepage of SustainAbility], [Online]. Available: http://www.sustainability.com/library/where-next-with-socialmedia-epoca-negocios (2011, 2/2/2011)

Ergazakis, E., Mtaxiotis, K., \& Tsitsanis, T. (2011). A state-of-the-art review of applied forms and areas, tools and technologies for e-participation. International Journal of Electronic Government Research, 7(1), 1-19.

European Commission (2009). ICT for a low carbon economy: Smart electricity distribution networks. Luxembourg: Office for Official Publications of the European Communities.

European Commission (2011). Policy | ICT for sustainable growth|Europa - information society. Homepage of European Commission. Online. Available: http://ec.europa.eu/ information_society/activities/sustainable_growth/policy/index_en.htm (2011, 3/4/ 2011) .

Fischer, E., \& Reuber, A. R. (2011). Social interaction via new social media: (how) can interactions on twitter affect effectual thinking and behavior? Journal of Business Venturing, 26(1), 1-18.

Forgues, D., \& Koskela, L. (2009). The influence of a collaborative procurement approach using integrated design in construction on project team performance. International Journal of Managing Projects in Business, 2(3), 370-385.

Fuchs, C. (2006). The implications of new information and communication technologies for sustainability. Environment, Development and Sustainability, 10(3), 291-309.

Garcia-Crespo, A., Colomo-Palacios, R., Gomez-Berbis, J., \& Ruiz-Mezcua, B. (2010). SEMO: A framework for customer social networks analysis based on semantics. Journal of Information Technology, 25(2), 178-188.

Genesys (2009). Using participatory web to drive exceptional customer experience. USA: Genesys Worldwide.

Ghani, N. A., Hamid, S., Targio Hashem, I. A., \& Ahmed, E. (2018). Social media big data analytics: A survey. Computers in Human Behavior. https://doi.org/10.1016/j.chb. 2018.08.039.

Giamanco, B., \& Gregoire, K. (2012, July-August). Tweet Me, Friend Me, Make Me Buy. Harvard Business Review, 88-93.

Gill, D. L., Dickinson, S. J., \& Scharl, A. (2008). Communicating sustainability: A web content analysis of North American, Asian and European firms. Journal of Communication Management, 12(3), 243-262.

Glaser, B. G., \& Strauss, A. L. (1967). The Discovery of Grounded Theory: Strategies for Qualitative Research. Chicago: Aldine Pub. Co.

Goh, C. M., Lee, S. P., He, W., \& Tan, P. S. (2007). Participatory web concepts and technologies for dynamic B2B integration. Emerging technologies and factory automation, 2007. ETFA (pp. 315). IEEE Conference on.

Gordon, S. (2006). Rise of the blog [journal-based website]. IEE Review, 52(3), 32-35.

Grabner-Krauter, S. (2009). Participatory web social networks: The role of trust. Journal of Business Ethics, 90(4), 505-522.

Gray, J., \& Rumpe, B. (2017). Models for the digital transformation. Software and Systems Modeling, 16(2), 307-308.

Gunasekaran, A., \& Ngai, E. W. T. (2004). Information systems in supply chain integration and management. European Journal of Operational Research, 159, 269-295.

Gupta, S., \& Kumar, V. (2013). Sustainability as corporate culture of a brand for superior performance. Journal of World Business, 48(3) (forthcoming).

Hagstrom, M., Hornby, J., \& Farrell, A. A. (2009). The evolving science of managing for sustainability: Using ICT to optimize environmental and economic outcomes. Geneva, Switzerland: World Economic Forum and INSEAD.

Hart, S. L., \& Milstein, M. B. (2003). Creating sustainable value. Academy of Management Executive, 17(2), 56-69.

Hauger, D., \& Kock, M. (2007). State of the art of adaptivity in e-learning platforms. Proceedings of the 15th workshop on adaptivity and user modeling in interactive systems (pp. 355). Hildesheim, Germany: University of Hildesheim.

Heath, J., \& Norman, W. (2004). Stakeholder theory, corporate governance and public management: What can the history of state-run enterprises teach us in the post-Enron era? Journal of Business Ethics, 53(3), 247-265.
Hazen, B. T., Boone, C. A., Ezell, J. D., \& Jones-Farmer, L. A. (2014). Data quality for data science, predictive analytics, and big data in supply chain management: An introduction to the problem and suggestions for research and applications. International Journal of Production Economics, 154, 72-80.

Hill, J. (2001). Thinking about a more sustainable business - an indicators approach. Corporate Environmental Strategy, 8(1), 30-38.

Hilty, L. M. (2008). Information technology and sustainability: Essays on the relationship between information technology and sustainable development. Norderstedt, Germany: Books on Demand.

Huberman, B. A., Romero, D. M., \& Wu, F. (2009). Crowd-sourcing, attention and productivity. Journal of Information Science, 35(6), Online. Available from: http://jis sagepub.com/content/35/6/758 16/02/2011

Huijboom, N., Broek, T., Frissen, V., Kool, L., Kotterink, B., Nielsen, M. M., \& Millard, J. (2009). Public services 2.0: Impact of social computing on public services. Luxembourg: European Communities.

IUCN, International Union for Conservation of Nature (2008). Shaping the future. Geneva, Switzerland: International Union for Conservation of Nature.

Java, A., Song, X., Finin, T., \& Tseng, B. (2007). Why we twitter: Understanding microblogging usage and communities. Joint 9th WEBKDD and 1st SNA-KDD workshop (pp. 56). California, USA: ACM.

Jeble, S., Dubey, R., Childe, S. J., Papadopoulos, T., Roubaud, D., \& Prakash, A. (2018). Impact of big data and predictive analytics capability on supply chain sustainability. International Journal of Logistics Management, 29(2), 513-538. https://doi.org/10. 1108/IJLM-05-2017-0134 (ISSN 0957-4093).

Jenkin, T. A., Webster, J., \& McShane, L. (2011). An agenda for 'green' information technology and systems research. Information and Organization, 21(1), 17-40.

Johnson, M., Redlbacher, F., \& Schaltegger, S. (2018). Stakeholder engagement for corporate sustainability: A comparative analysis of B2C and B2B companies. Corporate Social Responsibility and Environmental Management, 25(4), 659-673.

Jones, S., Irani, Z., Sivarajah, U., \& Love, E. D. P. (2017). Risks and rewards of cloud computing in the UK public sector: A reflection on three Organisational case studies. Information Systems Frontiers. https://doi.org/10.1007/s10796-017-9756-0.

Jones, T., \& D'Agostino, D. (2009). IT and sustainability: Bringing best practices to the business. London, UK: The Economist Intelligence Unit.

Juch, C., \& Stobbe, A. (2005). Blogs: The new magic formula for corporate communications? Deutsche Bank Research. Germany: Frankfurt am Main.

Kache, F., \& Seuring, S. (2017). Challenges and opportunities of digital information at the intersection of big data analytics and supply chain management. International Journa of Operations and Production Management, 37(1), 10-36.

Kalapesi, C., Willersdorf, S., \& Zwillenberg, P. (2010). "How the internet is transforming the U.K. economy". Boston Consulting Group.

Kambil, A. (2008). What is your web 5.0 strategy? The Journal of Business Strategy, 29(6), $56-58$.

Kapitan, S., Kennedy, A., \& Berth, N. (2019). Sustainably superior versus greenwasher: A scale measure of B2B sustainability positioning. Industrial Marketing Management, 76, 84-97.

Kaplan, A. M., \& Haenlein, M. (2010). Users of the world, unite! The challenges and opportunities of social media. Business Horizons, 53(1), 59.

Karkkainen, H., Jussila, J., \& Vaisanen, J. (2010). Social media use and potential in business-to-business companies' innovation. Proceedings of the 14th International Academic MindTrek Conference: Envisioning Future Media EnvironmentsACM, New York, NY, USA (pp. 228).

Karnouskos, S., \& Fokus, F. (2004). Mobile payment: A journey through existing procedures and standardization initiatives. IEEE Communication Surveys and Tutorials, 6(4), 44.

Keller, A., \& Hüsig, S. (2009). Ex ante identification of disruptive innovations in the software industry applied to web applications: The case of Microsoft's vs. Google's office applications. Technological Forecasting and Social Change, 76(8), 1044-1054.

Khanagha, S., Volberda, H., Sindhu, J., \& Oshri, I. (2013). Management innovation and adoption of emerging technologies: The case of cloud computing. European Management Review, 10, 51-67.

Kiang, M. Y., Raghu, T. S., \& Shang, K. H. (2000). Marketing on the internet - Who can benefit from an online marketing approach? Decision Support Systems, 27(4), 383-393.

Kietzmann, J. H., Hermkens, K., McCarthy, I. P., \& Silvestre, B. S. (2011). Social media? Get serious! Understanding the functional building blocks of social media. Business Horizons, 54, 241-251.

Kim, D. J., Yue, K., Hall, S. P., \& Gates, T. (2009). Global diffusion of the internet XV: Participatory web technologies, principles, and applications: A conceptual framework from technology push and demand pull perspective. Communications of the Association for Information Systems, 24(1), 657-672.

Lacy, P., Cooper, T., Hayward, R., \& Neuberger, L. (2010). A new era of sustainability. UK: UN Global Compact-Accenture.

Levy, M. (2009). Participatory web applications on knowledge management. Journal of Knowledge Management, 13(1), 120-134.

Li, C., Stromberg, C., \& North, J. (2007). Calculating the ROI of blogging: A case study. USA: Forrester Report.

Liu, X., \& Zhang, C. (2017). Corporate governance, social responsibility information disclosure, and enterprise value in China. Journal of Cleaner Production, 142, 1075-1084.

Loeser, F., Erek, K., Schmidt, N., Zarnekow, R., \& Kolbe, L. M. (2011). Aligning green IT with environmental strategies: Development of a conceptual framework that leverages sustainability and firm competitiveness. AMCIS 2011 proceedingsais electronic library (pp. 1).

Madden, N. (2008). 16/05/2008-last update. B2B in a participatory web world, part 2: Social media marketingHomepage of e-commerce times. Online. Available: http:// 
www.ecommercetimes.com/story/62988.html (20/06/2013, July 2013)

Manetti, G. (2011). The quality of stakeholder engagement in sustainability reporting: Empirical evidence and critical points. Corporate Social Responsibility and Environmental Management, 18(2), 110-122.

Mangold, W. G., \& Faulds, D. J. (2009). Social media: The new hybrid element of the promotion mix. Business Horizons, 52(4), 357-365.

Mankoff, J., Matthews, D., Fussell, S. R., \& Johnson, M. (2007). Leveraging social networks to motivate individuals to reduce their ecological footprints. Proceedings of the 40th Hawaii international conference on system sciences (pp. 1). Washington, DC, USA: IEEE Computer Society.

McKenna, P. (2008). Can we stop the internet destroying our planet? The New Scientist, 197(2637), 20-21.

Melville, N. (2010). Information systems innovation for environmental sustainability. Innovation for Environmental Sustainability, 34(1), 1-21.

Melville, N., Kraemer, K., \& Gurbaxani, V. (2004). Review: Information technology and organizational performance: An integrative model of it business value. MIS Quarterly, 28(2), 283-322.

Merono-Cerdan, A., \& Soto-Acosta, P. (2007). External web content and its influence on organizational performance. European Journal of Information Systems, 16(1), 66-80.

Michael, K., \& Miller, K. W. (2013). Big data: New opportunities and new challenges [guest editors' introduction]. Computer, 46(6), 22-24.

Michaelidou, N., Siamagka, N., \& Christodoulides, G. (2011). Usage, barriers and measurement of social media marketing: An exploratory investigation of small and medium B2B brands. Industrial Marketing Management, 40(7), 1153-1159.

Middleton, C. (2009). Can broadband support environmental sustainability? An exploration of claims at the household level. Telecommunication Journal of Australia, 59(1), 10.1-10.14.

Miles, M. B., \& Huberman, A. M. (1994). Qualitative Data Analysis (2nd edition). Thousand Oaks, CA: Sage Publications.

Mingers, J., Mutch, A., \& Willcocks, L. (2013). Critical realism in information systems research. MIS Quarterly, 37(3), 795-802.

Montalvo, R. E. (2016). Social media management. International Journal of Management \& Information Systems (IJMIS), 20(2), 45.

Mrkwicka, K., Kiessling, M., \& Kolbe, L. M. (2009). Potential of participatory web applications for viewer retention. Proceedings of the fifteenth Americas conference on in formation systems (pp. 485). San Francisco, California: AMCIS.

Mueller, J., Hutter, K., Fueller, J., \& Matzler, K. (2011). Virtual worlds as knowledge management platform ? A practice-perspective. Information Systems Journal, 21(6), 479-501.

Muller, G., Sonehara, N., Echizen, I., \& Wohlgemuth, S. (2011). Sustainable cloud com puting. Business \& Information Systems Engineering, 3(3), 129-131.

Noonan, J. (2008). Using collaboration tools to improve training. Industrial and Commercial Training, 40(1), 51-53

Ohbe, T., Ozono, T. \& Shintani, T. (2017). A sentiment polarity classifier for regional event reputation analysis. Paper presented at the proceedings of the international conference on web intelligence.

O'Reilly, T. (2007). What is participatory web: Design patterns and business models for the next generation of software. International Journal of Digital Economics, 65, 17-37.

Orlikowski, W. J., \& Gash, D. C. (1994). Technological frames: Making sense of information technology in organizations. ACM Transactions on Information Systems, 12, 174-207.

Osimo, D. (2008). Participatory web in government: Why and how? Luxembourg: European Communities.

Owen, D. L., Swift, T., \& Hunt, K. (2001). Questioning the role of stakeholder engagement in social and ethical accounting auditing and reporting. Accounting Forum, 25(3), 264-282.

Pan, S. L., \& Scarbrough, H. (1998). A socio-technical view of knowledge-sharing at Buckman laboratories. Journal of Knowledge Management, 2(1), 55-66.

Papagiannidis, S., Bourlakis, M., \& Li, F. (2008). Making real money in virtual worlds: MMORPGs and emerging business opportunities, challenges and ethical implications in metaverses. Technological Forecasting and Social Change, 75(5), 610-622.

Poole, E. S., \& Grudin, J. (2010). A taxonomy of Wiki genres in enterprise settings. In P. Ayers, \& F. Ortega (Eds.). Proceedings of the 6th international symposium on wikis and open collaboration (pp. 1). New York, USA: ACM Digital Library.

Prattipati, S. N. (2010). Sustainability and the role of information and communications technologies. Business Renaissance Quarterly, 5(2), 23-23-40.

Procter, R., Crump, J., Karstedt, S., Voss, A., \& Cantijoch, M. (2013). Reading the riots What were the police doing on twitter? Policing and Society, 23(4), 413-436.

Reddick, C. G., Chatfield, A. T., \& Ojo, A. (2017). A social media text analytics framework for double-loop learning for citizen-centric public services: A case study of a local government facebook use. Government Information Quarterly, 34(1), 110-125.

Rodriguez-Melo, A., \& Mansouri, S. A. (2011). Stakeholder engagement: defining strategic advantage for sustainable construction. Business Strategy and the Environment, 20(8), 539-552.

Rust, R. T., \& Espinoza, F. (2006). How technology advances influence business research and marketing strategy. Journal of Business Research, 59(10-11), 1072-1078.

Rybako, S., \& Seltzer, T. (2010). Dialogic communication in 140 characters or less: How fortune 500 companies engage stakeholders using twitter. Public Relations Review, 36, 336-341.

Serrat, O. (2017). Social network analysis knowledge solutions. Springer39-43.

Schoenherr, T., \& Cheri, S-P. (2015). Data science, predictive analytics, and big data in supply chain management: Current state and future potential. Journal of Business Logistics, 36(1), 120-132.

Shanthi, C., \& Pappa, N. (2017). An artificial intelligence based improved classification of two-phase flow patterns with feature extracted from acquired images. ISA Transactions, 68, 425-432.
Sharda, R., Delen, D., \& Turban, E. (2018). Business intelligence, analytics, and data science. Harlow, England: Pearson.

Shaughnessy, J. J., \& Zechmeister, E. B. (1985). Research methods in psychology. Alfred A. Knopf.

Sheth, J. N., Sethia, N. K., \& Srinivas, S. (2011). Mindful consumption: A customer-centric approach to sustainability. Journal of the Academy of Marketing Science, 39(1), 21-39.

Sheth, J. N., \& Sinha, M. (2015). B2B branding in emerging markets: A sustainability perspective. Industrial Marketing Management, 51, 79-88.

Shu, K., Sliva, A., Wang, S., Tang, J., \& Liu, H. (2017). Fake news detection on social media: A data mining perspective. ACM SIGKDD Explorations Newsletter, 19(1), $22-36$.

Sigala, M., \& Marinidis, D. (2012). Web map services in tourism: A framework exploring the organisational transformations and implications on business operations and models. International Journal of Business Information Systems, 9(4), 415-434.

Silverman, D. (2000). Doing Qualitative Research. Thousand Oaks, CA: Sage.

Sivarajah, U., Irani, Z., \& Weerakkody, V. (2015). Evaluating the use and impact of participatory web technologies in local government. Government Information Quarterly, 32(4), 473-487.

Sivarajah, U., Kamal, M. M., Irani, Z., \& Weerakkody, V. (2017). Critical analysis of big data challenges and analytical methods. Journal of Business Research, 70, 263-286.

Song, M., Cen, L., Zheng, Z., Fisher, R., Liang, X., Wang, Y., \& Huisingh, D. (2017). How would big data support societal development and environmental sustainability? Insights and practices. Journal of Cleaner Production, 142, 489-500.

Song, M. L., Fisher, R., Wang, J. L., \& Cui, L. B. (2016). Environmental performance evaluation with big data: Theories and methods. Annals of Operations Research, 1-14.

Starbird, K., Maddock, J., Orand, M., Achterman, P., \& Mason, R. M. (2014). Rumors, false flags, and digital vigilantes: Misinformation on Twitter after the 2013 Boston Marathon bombing. iConference 2014 Proceedings.

Stieglitz, S., Dang-Xuan, L., Bruns, A., \& Neuberger, C. (2014). Social media analytics: An interdisciplinary approach and its implications for information systems. Business \& Information Systems Engineering, 6(2), 89-96.

Stieglitz, S., Mirbabaie, M., Ross, B., \& Neuberger, C. (2018). Social media analytics Challenges in topic discovery, data collection, and data preparation. International Journal of Information Management, 39, 156-168.

Stone, M. (2009). Staying customer-focused and trusted: Participatory web and customer 2.0 in financial services. The Journal of Database Marketing and Customer Strategy Management, 16(2), 101-131.

Symon, G., \& Cassell, C. (1998). Qualitative methods and analysis in organizational research Newbury Park, CA: Sage.

Tapscott, D., \& Williams, A. D. (2009). The wiki workplace. USA: Blooomberg BusinessWeek.

Taylor, S. J., \& \& Bogdan, R. (1998). Introduction to qualitative research methods: A guidebook and resource (3rd ed.). Hoboken, NJ, US: John Wiley \& Sons Inc.

Teo, H., Chan, H., Wei, K., \& Zhang, Z. (2003). Evaluating information accessibility and community adaptivity features for sustainable virtual learning communities. Information Journal of Human-Computer Studies, 59(5), 671-697.

Tomkovicz, J. J. (2002). Technology and the threshold of the fourth amendment: A tale of two futures. Mississippi Law Journal, 72(1), 317-446.

Tredinnick, L. (2006). Participatory web and business: A pointer to the intranets of the future? Business Information Review, 23(4), 228-234.

Trusov, M., Bucklin, R., \& Pauwels, K. (2009). Effects of W-O-M versus traditional marketing. Findings from an internet social networking site. Journal of Marketing, 73(5), 90-102.

Tucker, H. (2011). Where next for social media? ITNOW, 53(5), 6-7.

Venkateswaran, R. (2001). Virtual private networks, Potentials, IEEE, 20(1), 11-15.

Visich, J. K., Li, S., Khumawala, B. M., \& Reyes, P. M. (2009). Empirical evidence of RFID impacts on supply chain performance. International Journal of Operations \& Production Management, 29(12), 1290-1315.

Visser, W. (2010). The age of responsibility: CSR 2.0 and the new DNA of business. Journal of Business Systems, Governance and Ethics, 5(3), 7-22.

Waage, S., Shah, R., \& Girshick, S. (2003). Information technology and sustainability: Enabling the future. International Journal of Corporate Sustainability, 10(4), 81-96.

Waller, M. A., \& Fawcett, S. E. (2013). Data science, predictive analytics, and big data: a revolution that will transform supply chain design and management. Journal of Business Logistics, 34(2), 77-84.

Wang, G., Gunasekaran, A., Ngai, E. W. T., \& Papadopoulos, T. (2016). Big data analytics in logistics and supply chain management: Certain investigations for research and applications. International Journal of Production Economics, 176, 98-110.

Wamba, S. F., Gunasekaran, A., Akter, S., Ren, S. J. F., Dubey, R., \& Childe, S. J. (2017). Bidata analytics and firm performance: Effects of dynamic capabilities. Journal of Business Research, 70, 356-365.

Wang, Y., \& Hajli, N. (2017). Exploring the path to big data analytics success in healthcare. Journal of Business Research, 70, 287-299.

Wang, W., Malthouse, E. C., Calder, B., \& Uzunoglu, E. (2017). B2B content marketing for professional services: In-person versus digital contacts. Industrial Marketing Management. https://doi.org/10.1016/j.indmarman.2017.11.006.

Waszak, P. M., Kasprzycka-Waszak, W., \& Kubanek, A. (2018). The spread of medical fake news in social media - The pilot quantitative study. Health Policy and Technology, $7(2), 115-118$

Waters, R. D., Burnett, E., Lammb, A., \& Lucas, J. (2009). Engaging stakeholders through social networking: How nonprofit organizations are using Facebook. Public Relations Review, 35(2), 102-106.

Watson, I., \& Lightfoot, D. J. (2003). Mobile working with Connexions. Facilities, 21(13/ 14), 347-352.

Watson, R. T., \& Zinkhan, G. M. (1997). Electronic commerce strategy: Addressing the key questions. Journal of Strategic Marketing, 5(4), 189-210. 
Westerman, G., Bonnet, D., \& McAfee, A. (2014). Leading digital: Turning technology into business transformation. Harvard Business Press.

Williamson, P. (2016). Take the time and effort to correct misinformation. Nature, 540 , 171. https://doi.org/10.1038/540171a.

World Commission on Environment and Development (1987). Our Common Future Oxford: Oxford University Press.

Wu, X., Zhu, X., Wu, G.-Q., \& Ding, W. (2014). Data mining with big data. IEEE Transactions on Knowledge and Data Engineering, Vol. 26(1), 97-107.

Wu, Y. J., Huang, S., Kuo, L., \& Wu, W. (2010). Management education for sustainability:
A web-based content analysis. The Academy of Management Learning and Education, 9(3), 520-531.

Yin, R. K. (2011). Applications of case study research. Sage.

Youssef, Y. M. A., Johnston, W. J., AbdelHamid, T. A., Dakrory, M. I., \& Seddick, M. G. S. (2018). A customer engagement framework for a B2B context. Journal of Business \& Industrial Marketing, 33(1), 145-152.

Zhang, Y., Ren, S., Liu, Y., \& Si, S. (2017). A big data analytics architecture for cleaner manufacturing and maintenance processes of complex products. Journal of Cleaner Production, 142, 626-641. 